\title{
Identification of Active Area as Active Center for CO Oxidation over Single Au Atom Catalyst
}

\author{
Yang Lou ${ }^{1,2, \#}$, Yafeng Cai ${ }^{1, \#}$, Wende Hu${ }^{1, \#}$, Li Wang ${ }^{1}$, Qiguang Dai ${ }^{1}$, Wangcheng Zhan ${ }^{1}$, \\ Yanglong Guo ${ }^{1}, \mathrm{P} . ~ H u^{1}$, Xiao-Ming Cao ${ }^{1 *}$, Jingyue $\mathrm{Liu}^{3 *}$, Yun Guo ${ }^{1^{*}}$ \\ ${ }^{1}$ School of Chemistry and Molecular Engineering, East China University of Science and Technology, \\ Shanghai 200237, China. \\ ${ }^{2}$ School of Chemical and Material Engineering, Jiangnan University, Wuxi, Jiangsu 214122, China. \\ ${ }^{3}$ Department of Physics, Arizona State University, Tempe, Arizona 85287, United States.
}

*Corresponding author: yunguo@ecust.edu.cn (Y.G);xmcao@ecust.edu.cn (X.C); jingyue.liu@asu.edu (J. L). 


\section{Table of Contents}

Figure $\mathrm{S1}$ Au particle size distribution of $1.3 \mathrm{wt} . \% \mathrm{Au} / \mathrm{Co}_{3} \mathrm{O}_{4}$ catalyst.

Figure S2 Representative SEM back-scattering image of 0.067 wt. $\% \mathrm{Au}_{1} / \mathrm{Co}_{3} \mathrm{O}_{4} \mathrm{SAC}$. Figure S3 Representative SEM back-scattering image of 0.047 wt. $\% \mathrm{Au}_{1} / \mathrm{Co}_{3} \mathrm{O}_{4} \mathrm{SAC}$. Figure S4 Representative SEM back-scattering image of 0.041 wt. $\% \mathrm{Au}_{1} / \mathrm{Co}_{3} \mathrm{O}_{4} \mathrm{SAC}$. Figure S5 Catalytic stability of 0.067 wt. $\% \mathrm{Au}_{1} / \mathrm{Co}_{3} \mathrm{O}_{4} \mathrm{SAC}$ for $\mathrm{CO}$ oxidation.

Figure S6 Representative SEM back-scattering image (a) and catalytic performance (b) of 0.095 wt. $\% \mathrm{Au} / \mathrm{Co}_{3} \mathrm{O}_{4}$.

Figure S7 Representative SEM back-scattering image of 0.45 wt.\% $\mathrm{Au} / \mathrm{Co}_{3} \mathrm{O}_{4}$.

Figure S8 The catalytic performance of and $\mathrm{CO}$ adsorption behavior on $\mathrm{Au}$ nanoparticles.

Figure S9 Optimized structures of bulk $\mathrm{Co}_{3} \mathrm{O}_{4}$ and $\mathrm{Au}_{1} / \mathrm{Co}_{3} \mathrm{O}_{4}$ SACs.

Figure S10 Optimized adsorption structure and adsorption energy $\left(-273^{\circ} \mathrm{C}\right)$ of $\mathrm{CO}$ and $\mathrm{O}_{2}$.

Figure S11 The Gibbs free energy profiles of $\mathrm{CO}$ oxidation over $\mathrm{Co}_{3} \mathrm{O}_{4}$ and $\mathrm{Au}_{1} / \mathrm{Co}_{3} \mathrm{O}_{4}$ SAC.

Figure S12 Charge transfer for single $\mathrm{Au}$ atom adsorption over pristine $\mathrm{Co}_{3} \mathrm{O}_{4}$ (100) (a) and in oxygen vacancy on $\mathrm{Co}_{3} \mathrm{O}_{4}(100)$ (b).

Figure S13 Low-temperature programmed $\mathrm{O}_{2}$ desorption over $\mathrm{Co}_{3} \mathrm{O}_{4}, 1.3$ wt.\% $\mathrm{Au} / \mathrm{Co}_{3} \mathrm{O}_{4}$ and 0.095 wt. $\% \mathrm{Au} / \mathrm{Co}_{3} \mathrm{O}_{4}$.

Figure S14 Low-temperature programmed $\mathrm{CO}$ surface reaction (CO-TPSR) over $\mathrm{Co}_{3} \mathrm{O}_{4}, 1.3$ wt. $\% \mathrm{Au} / \mathrm{Co}_{3} \mathrm{O}_{4}$ and 0.095 wt. $\% \mathrm{Au} / \mathrm{Co}_{3} \mathrm{O}_{4}$.

Figure S15 Fitting results of CO-DRIFTS of fresh 0.067 wt. $\% \mathrm{Au}_{1} / \mathrm{Co}_{3} \mathrm{O}_{4} \mathrm{SAC}$ at -80 ${ }^{\circ} \mathrm{C}$.

Figure S16 Reaction kinetics of $\mathrm{CO}$ oxidation over $\mathrm{Co}_{3} \mathrm{O}_{4}$ and $\mathrm{Au}_{1} / \mathrm{Co}_{3} \mathrm{O}_{4}$ samples.

Figure S17 Time-dependent mass spectra of $\mathrm{C}^{16} \mathrm{O}_{2}$ and $\mathrm{C}^{16} \mathrm{O}^{18} \mathrm{O}$ species during $\mathrm{C}^{16} \mathrm{O}+{ }^{18} \mathrm{O}_{2}$ pulse reaction over 0.047 wt. $\% \mathrm{Au}_{1} / \mathrm{Co}_{3} \mathrm{O}_{4} \mathrm{SAC}$.

Table $\mathrm{S1}$ Thermodynamic quantities for $\mathrm{CO}, \mathrm{O}_{2}$ and $\mathrm{CO}_{2}$ gases at experiment condition $\left(-75^{\circ} \mathrm{C}, 1 \mathrm{~atm}\right)$

Table S2 Thermodynamic quantities for different states along reaction mechanism at experiment condition $\left(-75^{\circ} \mathrm{C}, 1 \mathrm{~atm}\right)$

Table S3 Local optimized geometry structures of $\mathrm{Au}_{1} / \mathrm{Co}_{3} \mathrm{O}_{4} \mathrm{SAC}$ and the binding energy of single $\mathrm{Au}$ atom on the $\mathrm{Co}_{3} \mathrm{O}_{4}$

Table $\mathbf{S 4}$ The charge of Au atom in different states along reaction mechanism

Table 55 The calculated TOF of CO oxidation, surface main species and most key step over $\mathrm{Co}_{3} \mathrm{O}_{4}$ and $\mathrm{Au}_{1} / \mathrm{Co}_{3} \mathrm{O}_{4} \mathrm{SAC}$ based on microkinetic simulation upon DFT calculations

Supplemental Experimental Procedures

Supplemental References 


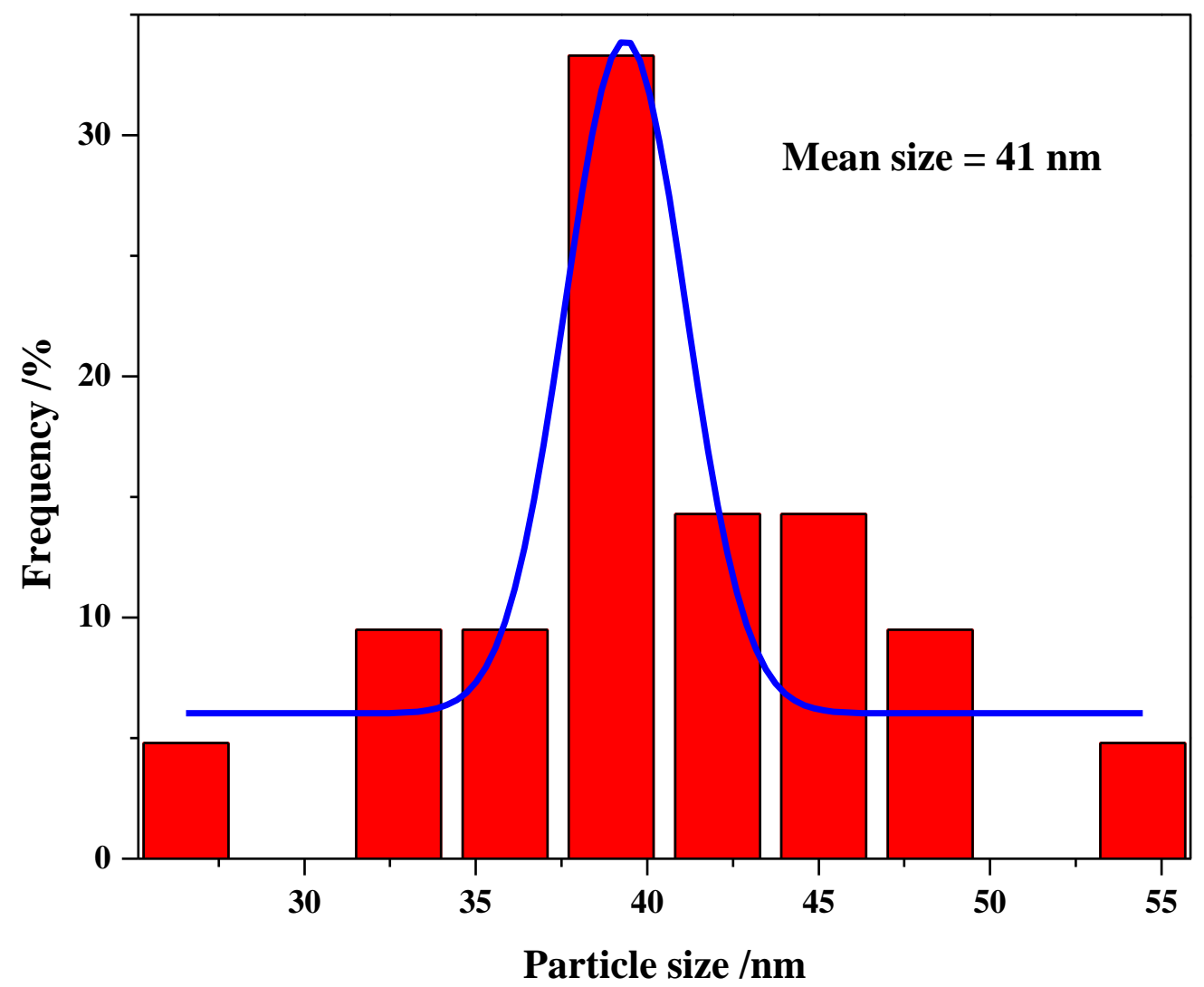

Figure S1 Au particle size distribution of 1.3 wt. $\%$ Au/ $\mathrm{Co}_{3} \mathrm{O}_{4}$ catalyst.

The data is acquired by using the software to count the number and measure the size of Au particles. The HAADF-STEM image is shown in Figure 1 (a). Au particles of 1.3 wt.\% $\mathrm{Au} / \mathrm{Co}_{3} \mathrm{O}_{4}$ are uniformly distributed on the surface of $\mathrm{Co}_{3} \mathrm{O}_{4}$ and the statistical sizes are $41 \mathrm{~nm}$. 


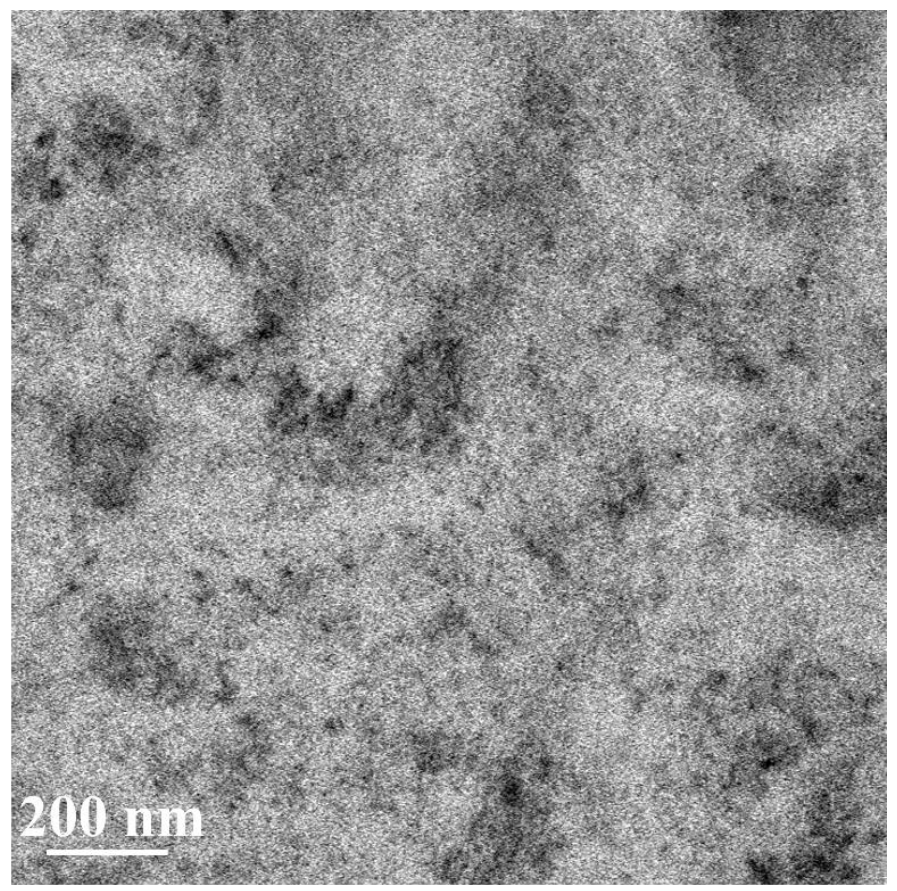

Figure S2 Representative SEM back-scattering image of 0.067 wt. \% $\mathrm{Au}_{1} / \mathrm{Co3O}_{4}$ SAC.

As shown in the SEM back-scattering images, there are no Au particles present on the surface of $\mathrm{Co}_{3} \mathrm{O}_{4}$ since any $\mathrm{Au}$ particles, if present, will show bright dots due to the strong contrast. 


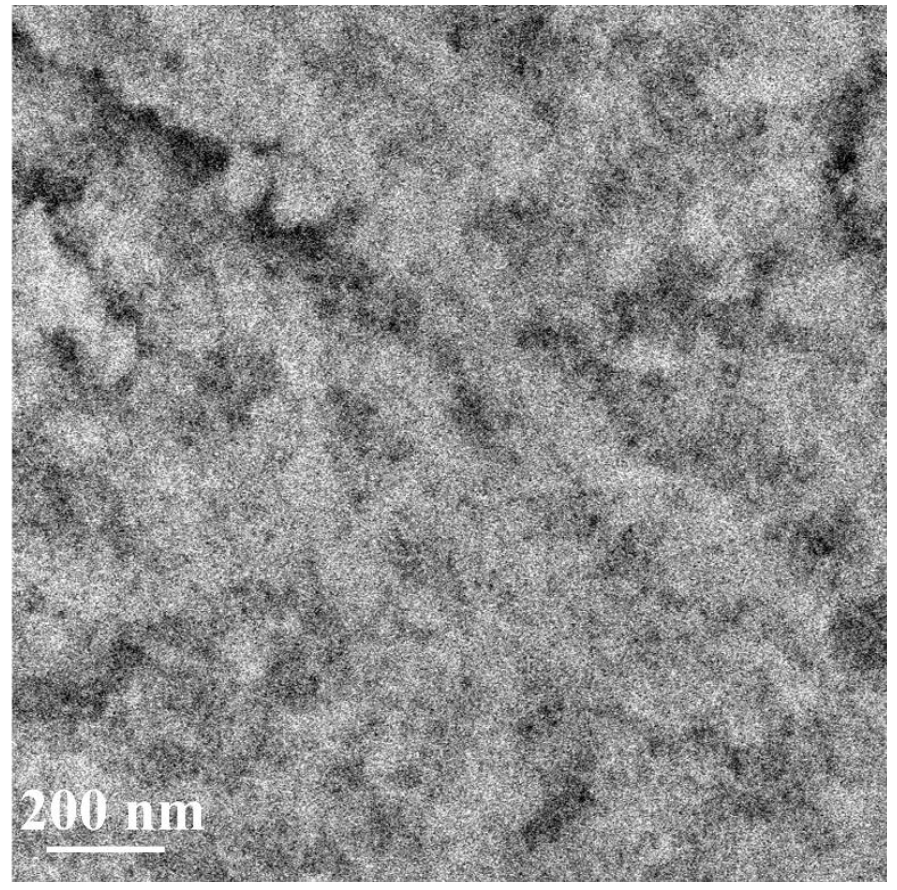

Figure S3 Representative SEM back-scattering image of 0.047 wt. \% $\mathrm{Au}_{1} / \mathrm{Co3}_{4}$ SAC.

As shown in the SEM back-scattering images, there are no Au particles present on the surface of $\mathrm{Co}_{3} \mathrm{O}_{4}$ since any Au particles, if present, will show bright dots due to the strong contrast. 


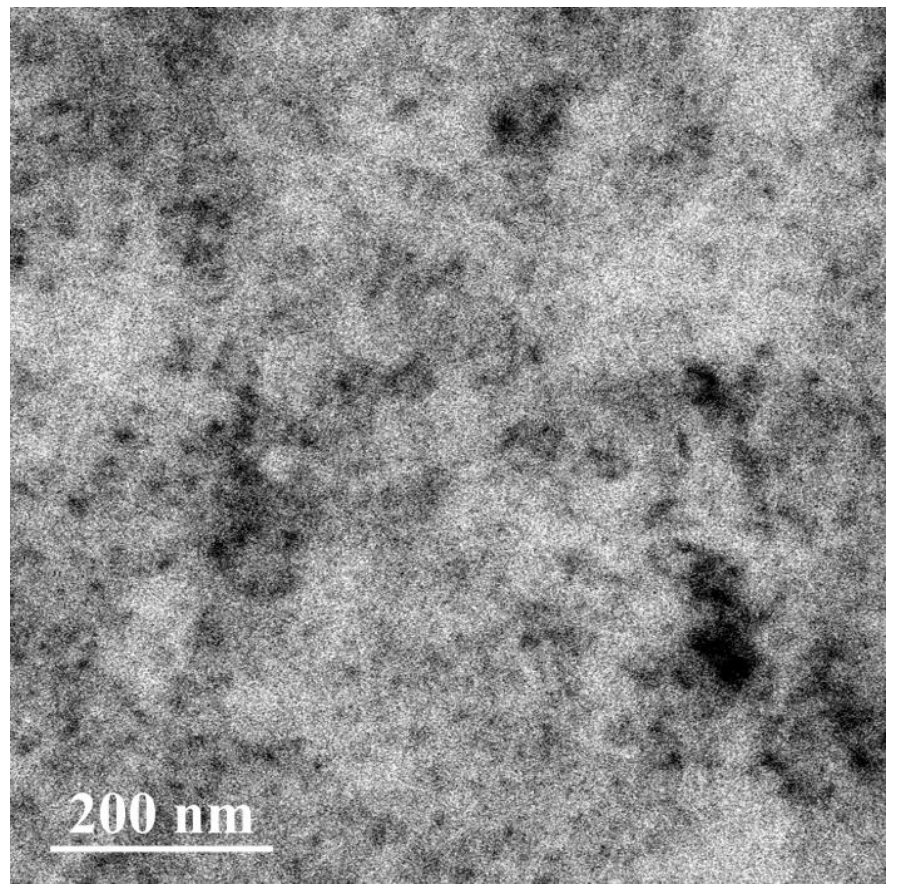

Figure S4 Representative SEM back-scattering image of 0.041 wt. \% $\mathrm{Au}_{1} / \mathrm{Co}_{3} \mathrm{O}_{4}$ SAC.

As shown in the SEM back-scattering images, there are no Au particles present on the surface of $\mathrm{Co}_{3} \mathrm{O}_{4}$ since any $\mathrm{Au}$ particles, if present, will show bright dots due to the strong contrast. 

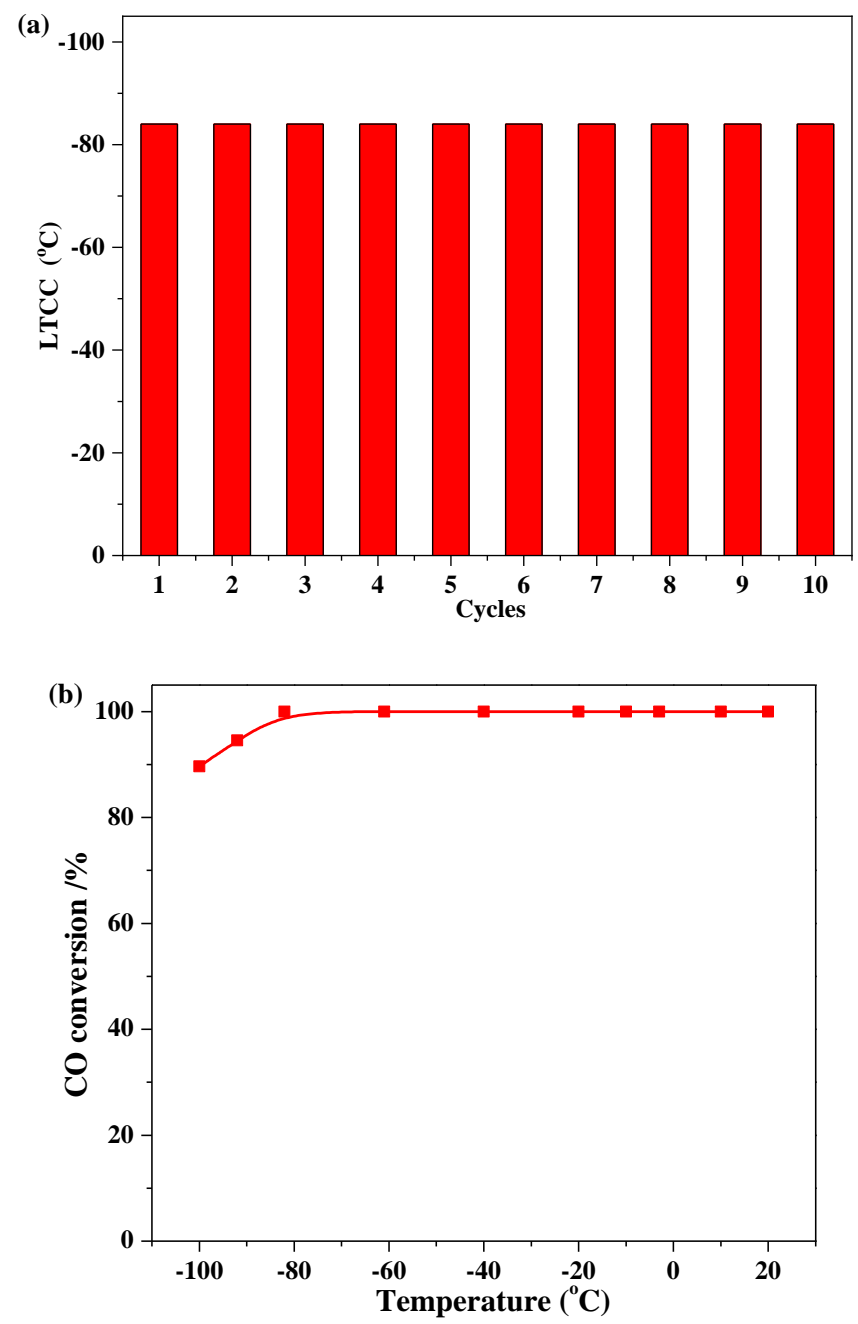

Figure S5 Catalytic stability of 0.067 wt. $\% \mathrm{Au}_{1} / \mathrm{Co}_{3} \mathrm{O}_{4} \mathrm{SAC}$ for $\mathrm{CO}$ oxidation. (a) Thermal stability of $0.067 \mathrm{wt} . \% \mathrm{Au}_{1} / \mathrm{Co}_{3} \mathrm{O}_{4} \mathrm{SAC}$ as a function of thermal treatment cycles; (b) Catalytic activity of 0.067 wt. $\% \quad \mathrm{Au}_{1} / \mathrm{Co}_{3} \mathrm{O}_{4} \mathrm{SAC}$ after storage at room temperature for one year. Thermal treatment conditions: treated at $300{ }^{\circ} \mathrm{C}$ for $40 \mathrm{~min}$ in the feed gas of 20 vol. $\% \mathrm{O}_{2} / \mathrm{N}_{2}$ each cycle. Reaction conditions: 1.0 vol.\% CO, 20.0 vol. $\% \mathrm{O}_{2}$ and $\mathrm{N}_{2}$ balance; $\mathrm{SV}=15,000 \mathrm{~mL} \cdot \mathrm{g}_{\text {cat }}^{-1} \cdot \mathrm{h}^{-1}$; pressure $=0.1 \mathrm{M} \mathrm{Pa}$.

In order to investigate the thermal stability of single $\mathrm{Au}$ atoms on the surface of $\mathrm{Co}_{3} \mathrm{O}_{4}$, the catalytic activity of $0.067 \mathrm{wt} . \% \mathrm{Au}_{1} / \mathrm{Co}_{3} \mathrm{O}_{4} \mathrm{SAC}$ after the thermal treatment is tested for 10 cycles. For each cycle, the catalyst was thermally treated at $300{ }^{\circ} \mathrm{C}$ for $40 \mathrm{~min}$ in the feed gas of 20 vol. $\% \mathrm{O}_{2} / \mathrm{N}_{2}$ and tested the catalytic activity under the normal evaluation process as described in Experimental Procedures. Then the same catalyst is used for the next cycle following the exactly same procedure. After 10 cycles as shown in Figure $\mathrm{S} 5$ (a), the 0.067 wt. $\% \mathrm{Au}_{1} / \mathrm{Co}_{3} \mathrm{O}_{4} \mathrm{SAC}$ shows no any significant deactivation on lowest temperature of complete conversion (LTCC) for $\mathrm{CO}$ oxidation $\left(-84{ }^{\circ} \mathrm{C}\right)$, which suggests that the single $\mathrm{Au}$ atoms on $\mathrm{Co}_{3} \mathrm{O}_{4}$ behave excellent thermal stability. After storage at room temperature for one year, no deterioration on the catalytic performance of 0.067 wt. $\% \mathrm{Au}_{1} / \mathrm{Co}_{3} \mathrm{O}_{4} \mathrm{SAC}$ is found as shown in Figure S5 (b). 


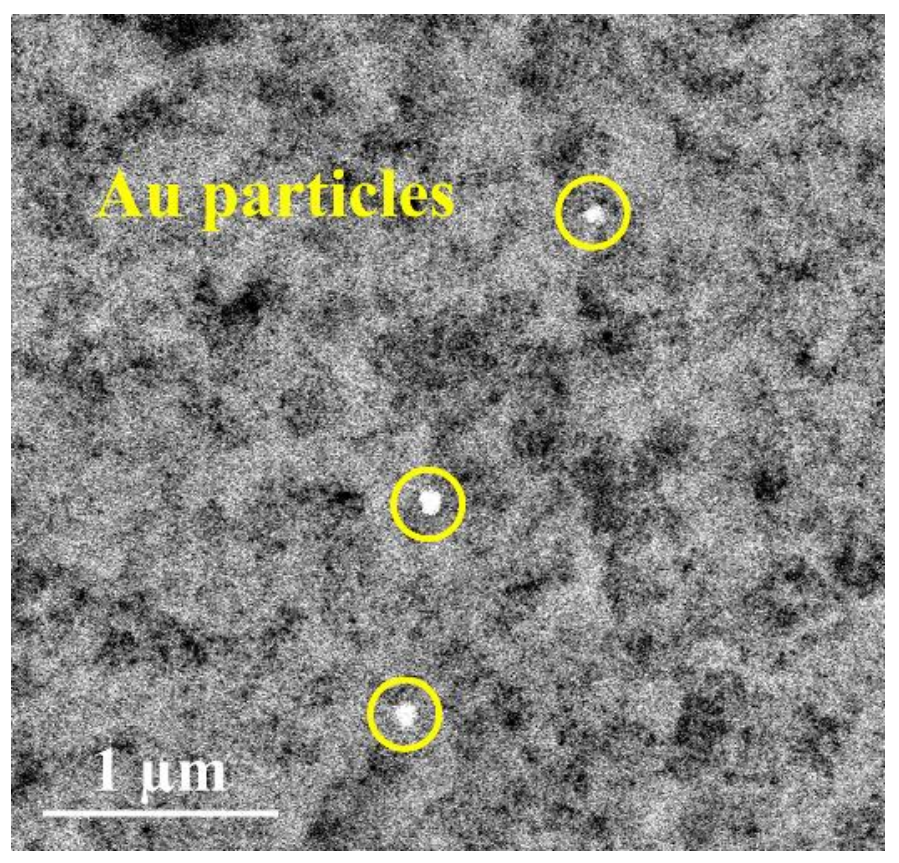

Figure S6 Representative SEM back-scattering image of 0.095 wt. \% $\mathrm{Au} / \mathrm{Coz}_{4}$.

As shown in the SEM back-scattering image (Figure S6), one can observe the $\mathrm{Au}$ particles present on the surface of $\mathrm{Co}_{3} \mathrm{O}_{4}$. 


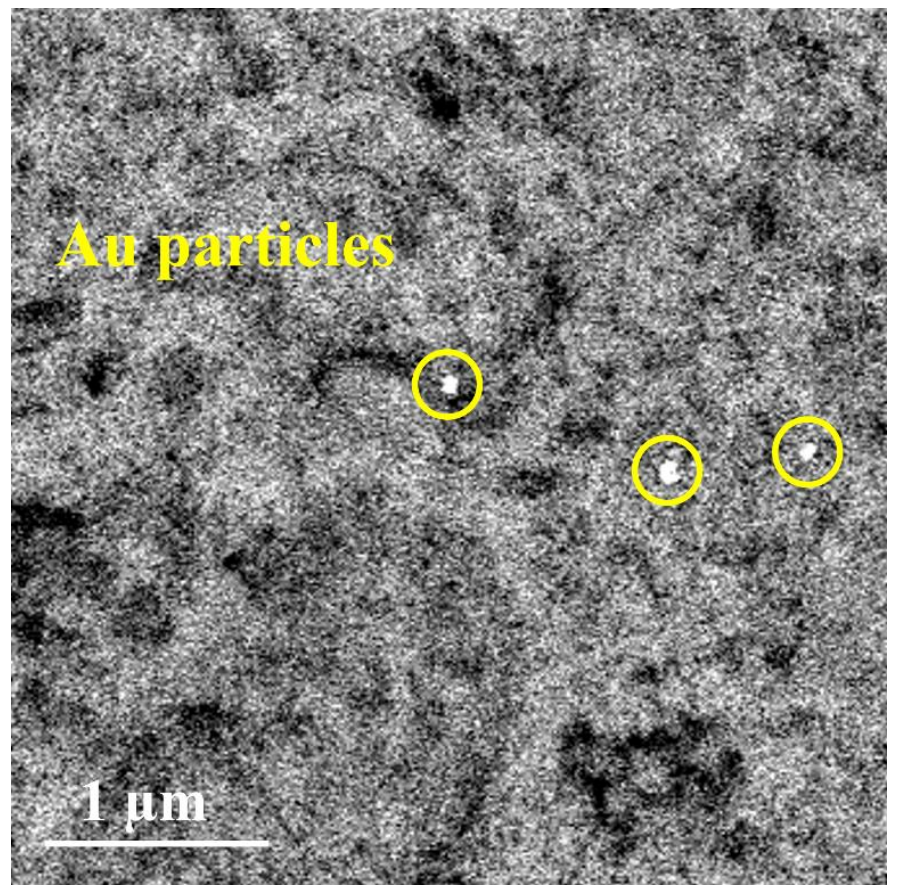

Figure S7 Representative SEM back-scattering image of 0.45 wt. \% $\mathrm{Au} / \mathrm{Co3}_{3}$.

As shown in the SEM back-scattering images, one can observe the Au particles present on the surface of $\mathrm{Co}_{3} \mathrm{O}_{4}$ from the different locations. 

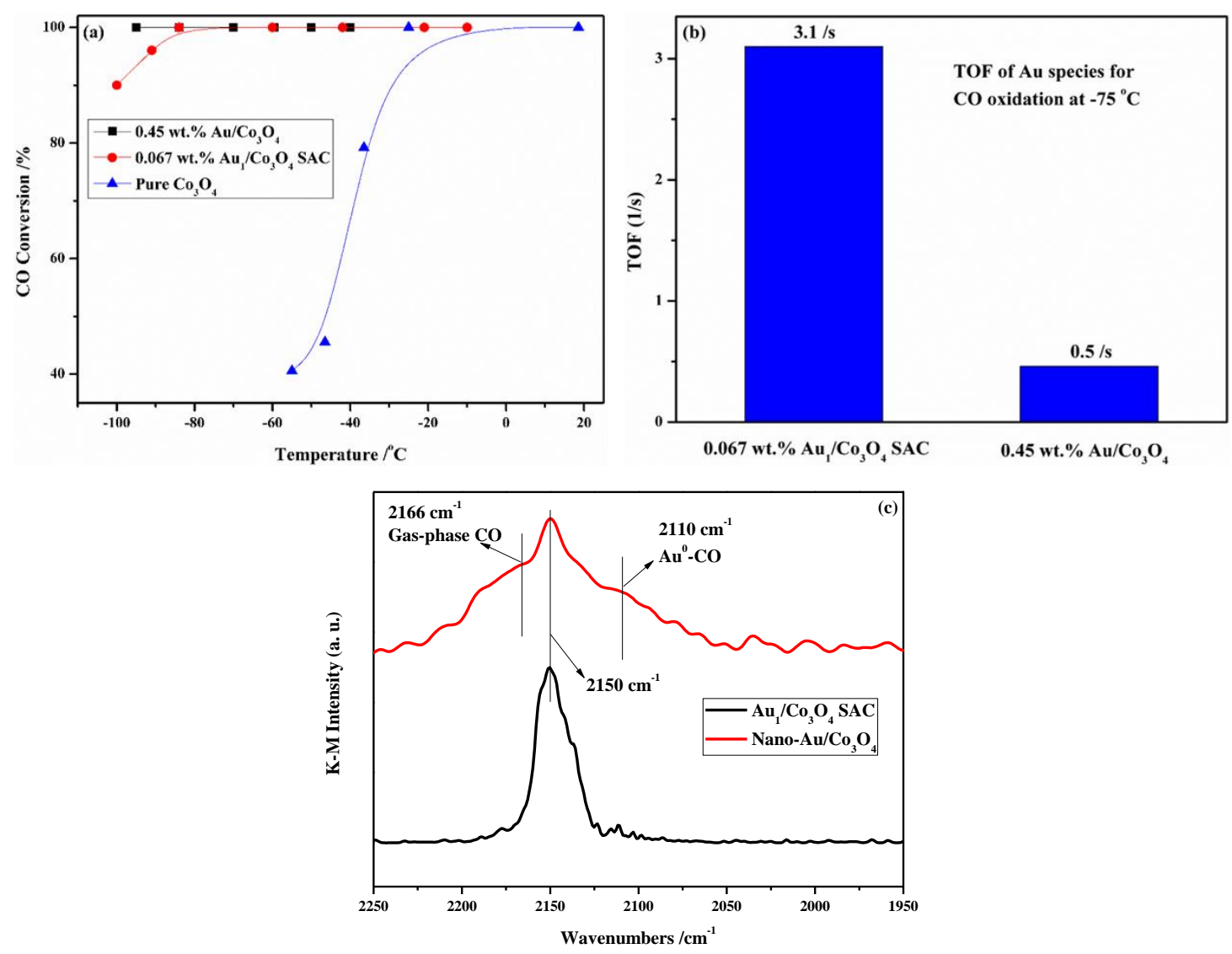

Figure S8 The catalytic performance of and $\mathrm{CO}$ adsorption behavior on $\mathrm{Au}$ nanoparticles. The catalytic activity of 0.45 wt. $\% \mathrm{Au} / \mathrm{Co}_{3} \mathrm{O}_{4}, 0.067$ wt. $\% \mathrm{Au}_{1} / \mathrm{Co}_{3} \mathrm{O}_{4}$ and pure $\mathrm{Co}_{3} \mathrm{O}_{4}$ for $\mathrm{CO}$ oxidation (a) and the TOF of $0.45 \mathrm{wt} . \% \mathrm{Au} / \mathrm{Co}_{3} \mathrm{O}_{4}$ and 0.067 wt. $\% \mathrm{Au}_{1} / \mathrm{Co}_{3} \mathrm{O}_{4}$ (b). CO-DRIFTs of nano- $\mathrm{Au} / \mathrm{Co}_{3} \mathrm{O}_{4}\left(0.45\right.$ wt. $\%$ Au/ $\left./ \mathrm{Co}_{3} \mathrm{O}_{4}\right)$ and $\mathrm{Au}_{1} / \mathrm{Co}_{3} \mathrm{O}_{4}$ SAC (0.067 wt. $\%$ $\left.\mathrm{Au}_{1} / \mathrm{Co}_{3} \mathrm{O}_{4} \mathrm{SAC}\right)$ at $-80{ }^{\circ} \mathrm{C}(\mathrm{c})$.

The $\mathrm{Au}$ particles on $\mathrm{Co}_{3} \mathrm{O}_{4}$ were synthesized by increasing the Au loading to $0.45 \mathrm{wt} . \%$, denoted as $0.45 \mathrm{wt} . \% \mathrm{Au} / \mathrm{Co}_{3} \mathrm{O}_{4}$. The synthesized $0.45 \mathrm{wt} . \% \mathrm{Au} / \mathrm{Co}_{3} \mathrm{O}_{4}$ catalyst should simultaneously contain Au particles (Figure S7 in the supplementary materials) and single $\mathrm{Au}$ atoms based on the experimental evidences of $1.3 \mathrm{wt} . \% \mathrm{Au} / \mathrm{Co}_{3} \mathrm{O}_{4}$ (Figure 1a in the main manuscript) although the particle size is not well controlled. As shown in Figure S8a, the LTCC of $0.45 \mathrm{wt} . \% \mathrm{Au} / \mathrm{Co}_{3} \mathrm{O}_{4}$ is $-90{ }^{\circ} \mathrm{C}$, which is lower than that of 0.067 wt. $\% \mathrm{Au}_{1} / \mathrm{Co}_{3} \mathrm{O}_{4} \mathrm{SAC}\left(\mathrm{LTCC}\right.$ of $-84{ }^{\circ} \mathrm{C}$ ). However, the TOF of Au species in 0.067 wt. $\% \mathrm{Au}_{1} / \mathrm{Co}_{3} \mathrm{O}_{4} \mathrm{SAC}\left(3.1 / \mathrm{s}\right.$ at $\left.-75^{\circ} \mathrm{C}\right)$ is significantly higher than that in 0.45 wt. $\% \mathrm{Au} / \mathrm{Co}_{3} \mathrm{O}_{4}\left(0.5 / \mathrm{s}\right.$ at $\left.-75^{\circ} \mathrm{C}\right)$ as shown in Figure $\mathrm{S} 8 \mathrm{~b}$.

The adsorption behavior of $\mathrm{CO}$ on $\mathrm{Au}$ nanoparticles is mainly determined by the geometric structure and oxidation state of Au species. $\mathrm{CO}$ adsorption on Au particles shows significant feature of metallic state as shown in Figure S8c. The data of CO adsorption on $\mathrm{Au}$ particles suggests beside the overlapping of gaseous $\mathrm{CO}$ peak (centered at $2166 \mathrm{~cm}^{-1}$ ), there is $\mathrm{CO}$ adsorption peak on Au oxidative state (centered at $2150 \mathrm{~cm}^{-1}$ ), similar to that of single Au atoms, which should be the reason for the high catalytic activity of Au nanoparticles as shown in Figure S8a. Furthermore, there is another $\mathrm{CO}$ adsorption peak on metallic state (centered at $2110 \mathrm{~cm}^{-1}$ ), which may be the reason for the low TOF of $\mathrm{Au}$ species in particles for $\mathrm{CO}$ oxidation. 


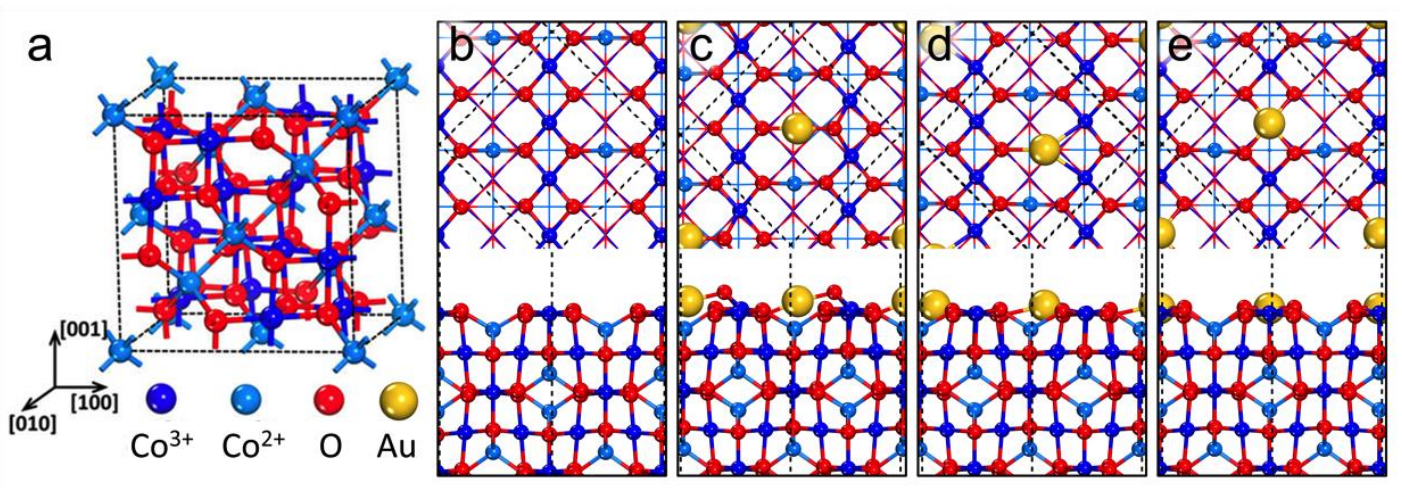

Figure S9 Optimized structures of bulk $\mathrm{Co}_{3} \mathrm{O}_{4}$ and $\mathrm{Au}_{1} / \mathrm{Co}_{3} \mathrm{O}_{4} \mathrm{SACs}_{\text {. The bulk }}$ structure of $\mathrm{Co}_{3} \mathrm{O}_{4}$ (a), and the top view (up) and side view (down) of optimized structures of pristine $\mathrm{Co}_{3} \mathrm{O}_{4}(100)$ (b), the single $\mathrm{Au}$ atom adsorbed pristine $\mathrm{Co}_{3} \mathrm{O}_{4}(100)$ (c), the single $\mathrm{Au}$ atom adsorbed in oxygen vacancy on $\mathrm{Co}_{3} \mathrm{O}_{4}$ (100) (d) and the single $\mathrm{Au}$ atom adsorbed in cobalt vacancy on $\mathrm{Co}_{3} \mathrm{O}_{4}(100)(\mathrm{e})$, respectively. $\mathrm{Co}^{3+}, \mathrm{Co}^{2+}, \mathrm{Au}$ and oxygen are shown in dark blue, light blue, yellow and red, respectively.

The spinel $\mathrm{Co}_{3} \mathrm{O}_{4}$ adopted as the matrix of the catalyst was modeled by a conventional cubic unit cell containing $32 \mathrm{O}$ and $24 \mathrm{Co}$ using Monkhorst Pack k-point grids of $4 \times 4 \times 4$ for sampling its Brillion zone, as shown in Figure S9. According to the HAADF-STEM images, the single $\mathrm{Au}$ atom was simulated in the (100) surface of $\mathrm{Co}_{3} \mathrm{O}_{4}$ with $\mathrm{Au}$ atom adsorbed over clean surface and surface with oxygen vacancy or cobalt vacancy existence in a $(\sqrt{2} \times \sqrt{2})$ supercell containing 8 layers of Co-O slab and with a vacuum layer $15 \AA$. A $3 \times 3 \times 1$ k-point mesh was used for these surface slabs. After binding energy filter (Table S3), we end up with three relatively stable structures, as shown in Figure S9 c-e. In these three stable structures, the single Au atom is binding in clean surface, three coordinated lattice oxygen vacancy and trivalence cobalt cation vacancy respectively. The structure of Figure S9 c-d can match the HAADF-STEM images of Figure $1 \mathrm{c}$ and the structure of Figure $\mathrm{S} 9$ e can match the HAADF-STEM images of Figure $1 \mathrm{~b}$.

The $\mathrm{Co}_{3} \mathrm{O}_{4}$ (100) surface has two types of terminations denoted as $\mathrm{Co}_{3} \mathrm{O}_{4}$ (100)-A and $\mathrm{Co}_{3} \mathrm{O}_{4}$ (100)-B, while $\mathrm{Co}_{3} \mathrm{O}_{4}$ (100)-B is much more energetically favoured. ${ }^{1}$ Hence, $\mathrm{Co}_{3} \mathrm{O}_{4}(100)$ - $\mathrm{B}$ is used to study the $\mathrm{CO}$ oxidation. 


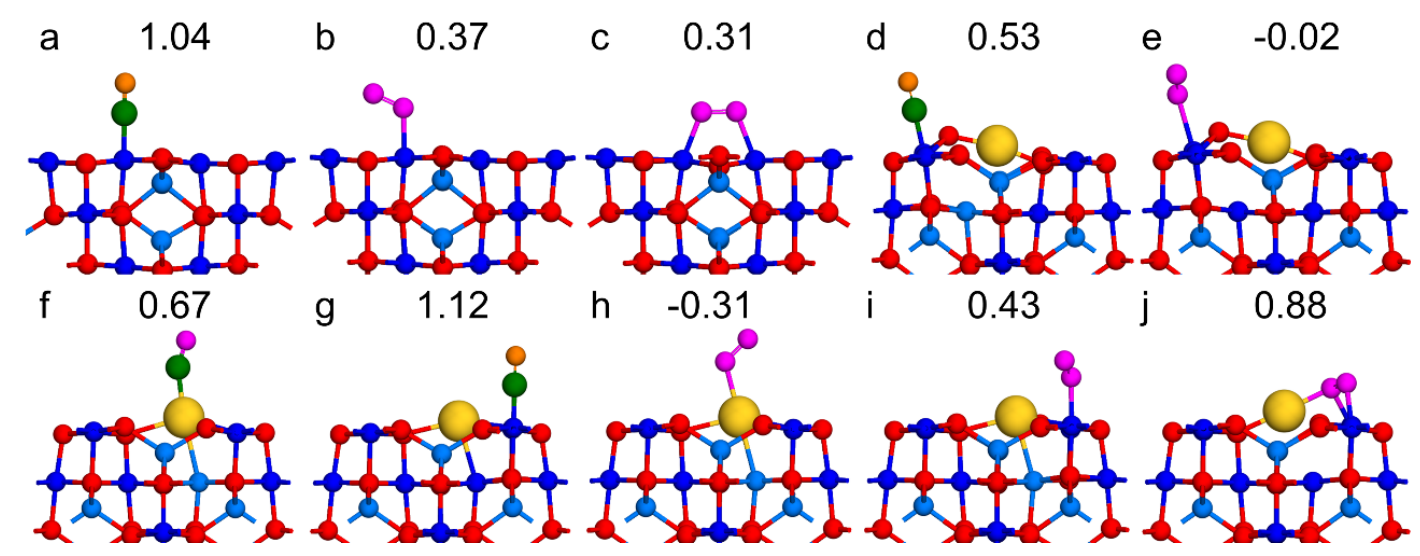

Figure S10 Optimized adsorption structure and adsorption energy of $\mathrm{CO}$ and $\mathrm{O}_{2}$. $\mathrm{Co}_{3} \mathrm{O}_{4}(001)(\mathrm{a}-\mathrm{c}), \mathrm{Au}_{1} / \mathrm{Co}_{3} \mathrm{O}_{4}(001)(\mathrm{d}-\mathrm{e})$ and $\mathrm{Au}_{1} / \mathrm{O}_{\mathrm{v}}-\mathrm{Co}_{3} \mathrm{O}_{4}(001)(\mathrm{f}-\mathrm{j}) \cdot \mathrm{Co}^{3+}, \mathrm{Co}^{2+}, \mathrm{Au}$, $\mathrm{C}$, lattice oxygen, molecule oxygen and oxygen in $\mathrm{CO}$ are shown in dark blue, light blue, yellow, green, red, magenta and orange, respectively. Energy unit: eV.

The adsorption energies $E_{\mathrm{ad}}(x)$ are calculated following

$$
E_{\mathrm{ad}}(x)=E(x)+E(\operatorname{surf})-E\left(x^{*}\right)
$$

where $E\left(x^{*}\right), E(x)$, and $E(\operatorname{surf})$ are the total energies of adsorbates, gaseous adsorbates, and bare surface, respectively. Notably, the adsorption energies of $\mathrm{CO}$ are stronger than those of $\mathrm{O}_{2}$ at all the sites. On the $\mathrm{Au}_{1} / \mathrm{Co}_{3} \mathrm{O}_{4}$ surface, the $\mathrm{O}_{2}$ could not be adsorbed. $\mathrm{CO}$ could adsorb at both Co site $(0.53 \mathrm{eV})$ and $\mathrm{Au}$ site $(0.21 \mathrm{eV})$, but preferentially at the neighboring Co site of the Au site. By contrast, for the $\mathrm{Au}_{1} / \mathrm{O}_{\mathrm{v}}-\mathrm{Co}_{3} \mathrm{O}_{4}$ surface, both the $\mathrm{Au}$ and $\mathrm{Co}$ sites are active sites, of which the former are more inclined to adsorb the $\mathrm{CO}$; the adsorption energy of $\mathrm{CO}$ on $\mathrm{Au}$ sites in $\mathrm{Au}_{1} / \mathrm{O}_{\mathrm{v}}-\mathrm{Co}_{3} \mathrm{O}_{4} \mathrm{SAC}$ is $0.67 \mathrm{eV}$. Besides, compared to the pristine $\mathrm{Co}_{3} \mathrm{O}_{4}(001)$ surface, the $\mathrm{O}_{2}$ activation has also improved at the interface of Au-Co with the adsorption energy increasing from $0.37 \mathrm{eV}$ to $0.88 \mathrm{eV}$. 


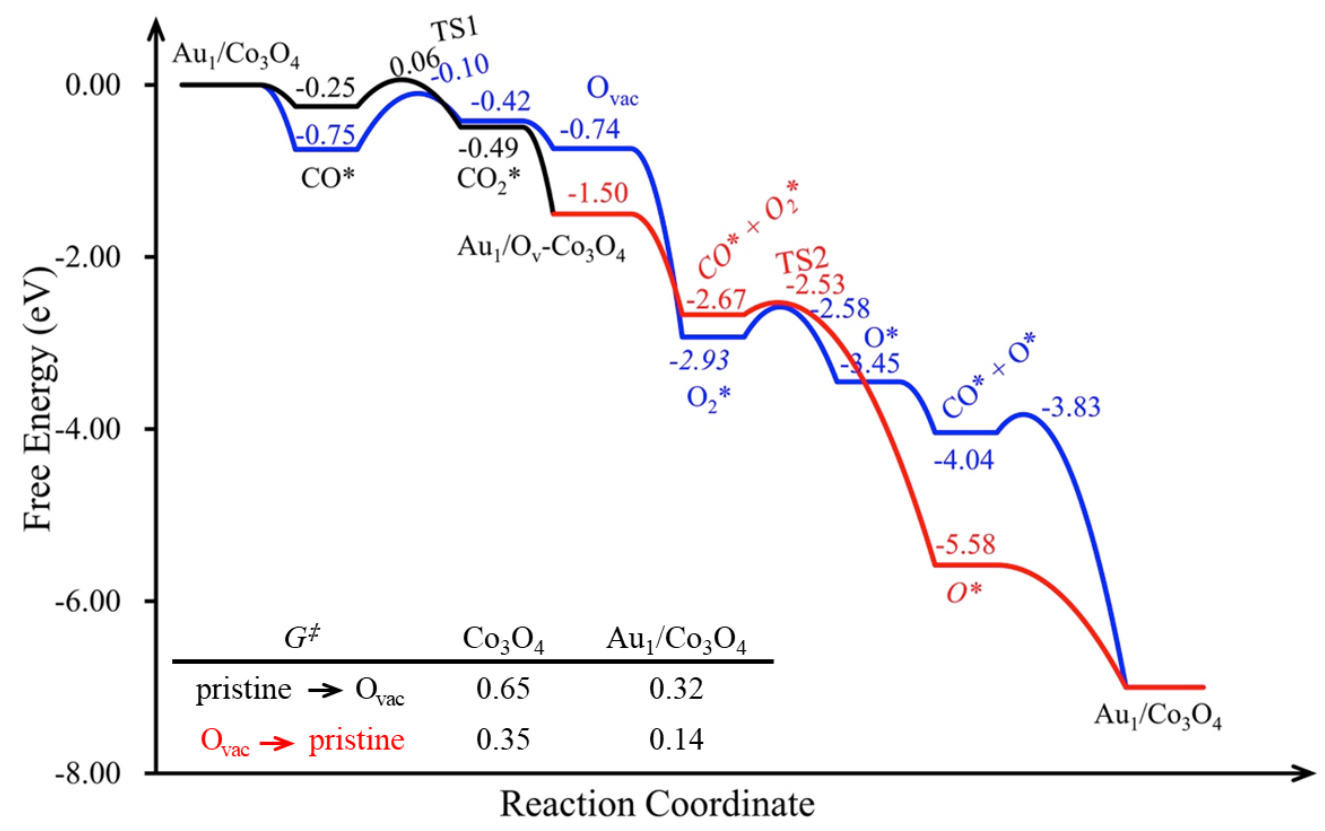

Figure S11 The Gibbs free energy profiles of $\mathrm{CO}$ oxidation over $\mathrm{Co}_{3} \mathrm{O}_{4}$ and $\mathrm{Au}_{1} / \mathrm{Co}_{3} \mathrm{O}_{4} \mathrm{SAC}$. The black, red and blue line and label corresponding to the Pathwayмvк and the Pathwayl-H over $\mathrm{Au}_{1} / \mathrm{Co}_{3} \mathrm{O}_{4} \mathrm{SAC}$ and the optimal pathway $\mathrm{Co}_{3} \mathrm{O}_{4}$, respectively. The insert table lists the maximum energy barriers of reactions at a specific stage. Energy unit: eV.

As shown in Figure S11, the reaction barrier of Pathway $\mathrm{L}_{\mathrm{H}}$ is much lower than that of Pathway ${ }_{\mathrm{MvK}}$, nevertheless, the Pathway ${ }_{\mathrm{MvK}}$ is still highly active, the reaction barrier of which is significantly lowered than that of pristine $\mathrm{Co}_{3} \mathrm{O}_{4}(100)(0.65 \mathrm{eV})$. 
(a)

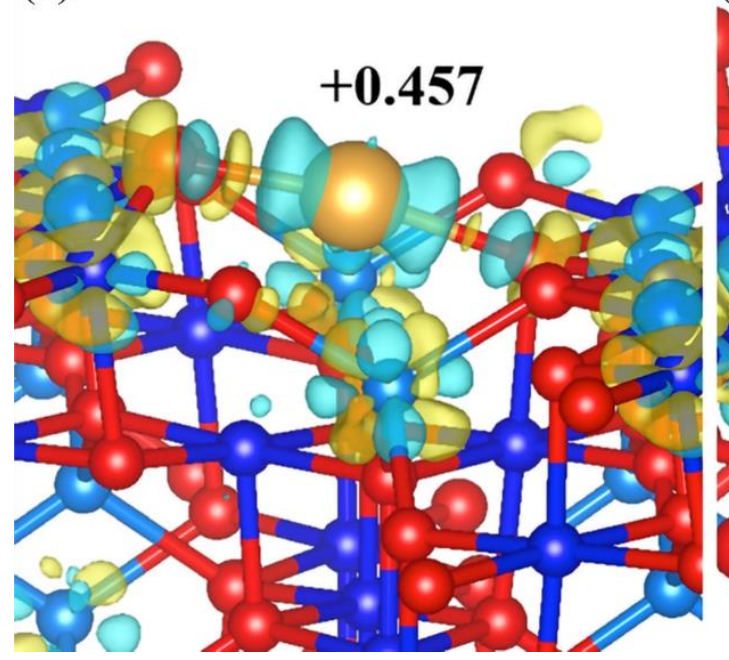

(b)

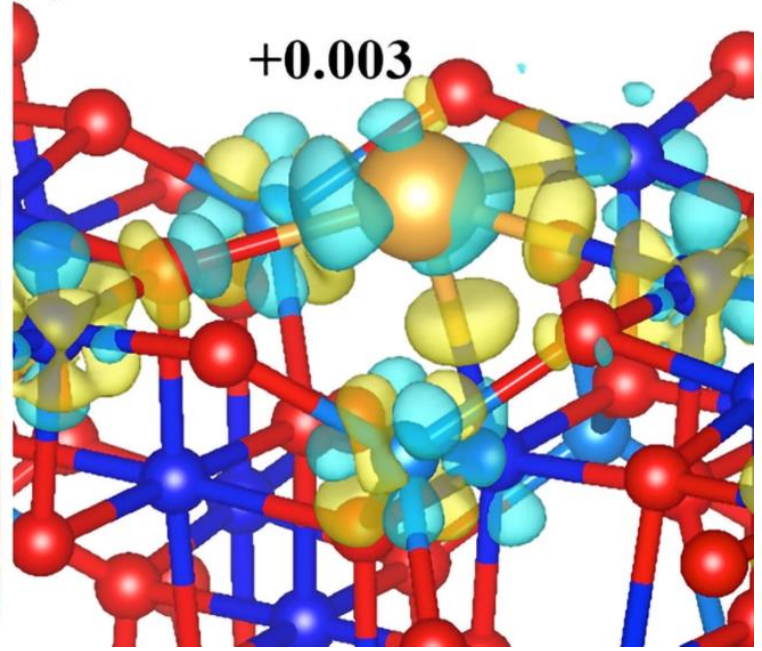

Figure $\mathrm{S1}_{2}$ Charge transfer for single $\mathrm{Au}$ atom adsorption over pristine $\mathrm{Co}_{3} \mathrm{O}_{4}$ (100) (a) and in oxygen vacancy on $\mathrm{Co}_{3} \mathrm{O}_{4}(100)(b)$. The yellow and green isosurfaces correspond to the increase in the number of electrons and the depletion zone, respectively. The isosurface value is $0.008 \mathrm{e} \mathrm{A}^{-3}$.

As shown in Figure $\mathrm{S} 12$, in $\mathrm{Au}_{1} / \mathrm{Co}_{3} \mathrm{O}_{4}$, the $\mathrm{Au}$ atom transfers electrons to lattice oxygen and exhibits a positive charge of +0.457 . While in $\mathrm{Au}_{1} / \mathrm{O}_{\mathrm{v}}-\mathrm{Co}_{3} \mathrm{O}_{4}$, the $\mathrm{Au}$ atom obtains electrons from three Co ions and transfers those electrons to the lattice oxygen. This dual electron transfer effect makes the Au atom exhibit a positive charge of +0.003 . 


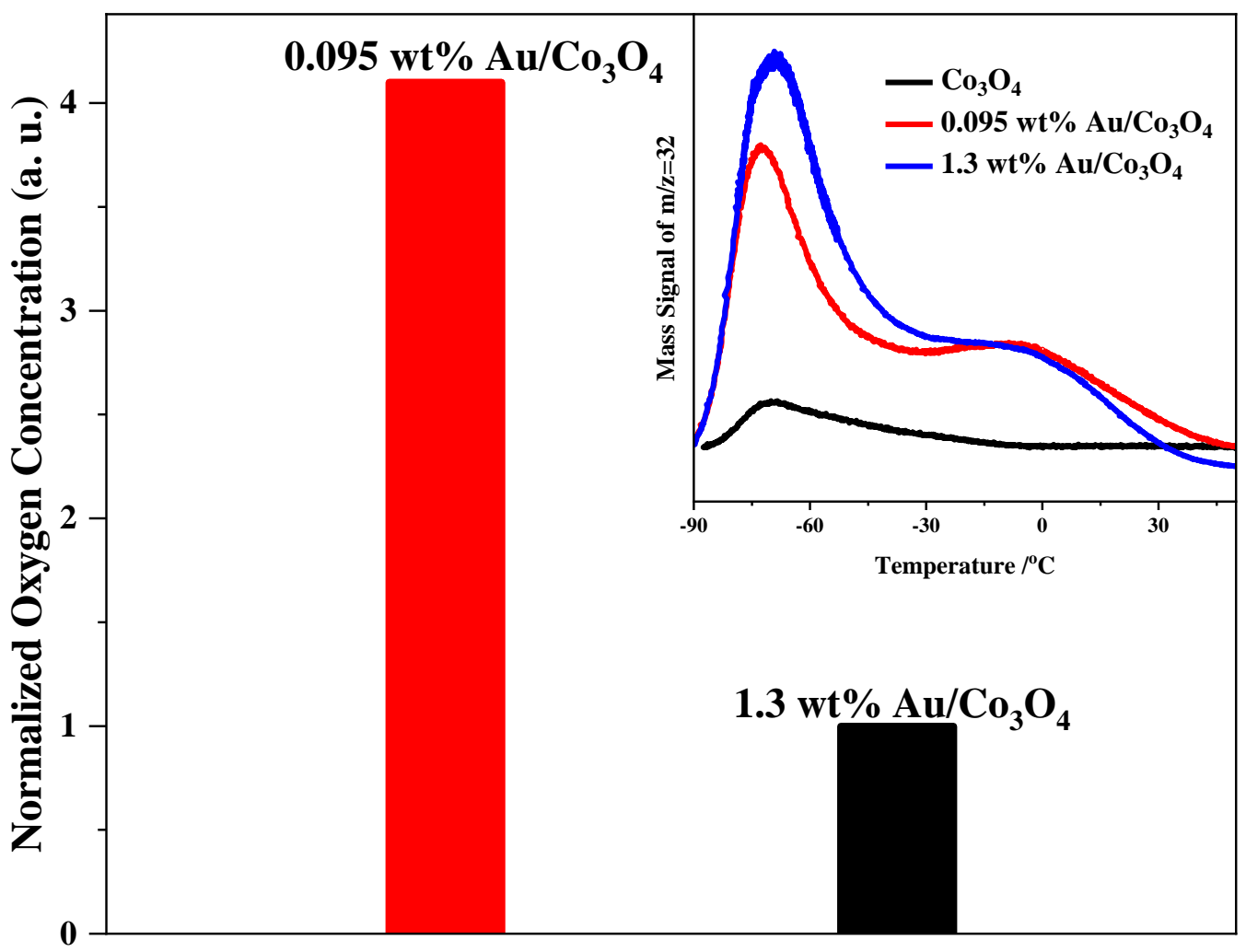

Figure S13 Low-temperature programmed $\mathrm{O}_{2}$ desorption over $\mathrm{Co}_{3} \mathrm{O}_{4}, 1.3$ wt. \% $\mathrm{Au} / \mathrm{Co3}_{4}$ and 0.095 wt. $\% \mathrm{Au} / \mathrm{Co3}_{4}$.

The peak area of $\mathrm{O}_{2}$ desorption peak is generally proportional to the amount of adsorbed $\mathrm{O}_{2}$ species. ${ }^{2-4}$ The low-temperature programmed $\mathrm{O}_{2}$-desorption curves clearly show that the presence of $\mathrm{Au}$ species of 0.095 wt. $\% \mathrm{Au} / \mathrm{Co}_{3} \mathrm{O}_{4}$ and 1.3 wt. $\% \mathrm{Au} / \mathrm{Co}_{3} \mathrm{O}_{4}$ significantly increases the amount of adsorbed $\mathrm{O}_{2}$ by about 5.2 and 14.0 times respectively compared with that of pure $\mathrm{Co}_{3} \mathrm{O}_{4}$, which indicates that the presence of $\mathrm{Au}$ species greatly enhances the activation of $\mathrm{O}_{2}$.

If we subtract $\mathrm{O}_{2}$ desorption peak area of pure $\mathrm{Co}_{3} \mathrm{O}_{4}$, then we can normalize the peak area to the total $\mathrm{Au}$ atoms of 1.3 wt. $\% \mathrm{Au} / \mathrm{Co}_{3} \mathrm{O}_{4}$ and 0.095 wt. $\% \mathrm{Au} / \mathrm{Co}_{3} \mathrm{O}_{4}$ to characterize the capability of $\mathrm{O}_{2}$ activation of these two $\mathrm{Au} / \mathrm{Co}_{3} \mathrm{O}_{4}$ catalysts. The capability of $\mathrm{O}_{2}$ activation per $\mathrm{Au}$ atom of $0.095 \mathrm{wt} . \% \mathrm{Au} / \mathrm{Co}_{3} \mathrm{O}_{4}$ is around 4.1 times higher than that of $1.3 \mathrm{wt} . \% \mathrm{Au} / \mathrm{Co}_{3} \mathrm{O}_{4}$. Although the $0.095 \mathrm{wt} . \% \mathrm{Au} / \mathrm{Co}_{3} \mathrm{O}_{4}$ contains single $\mathrm{Au}$ atoms and $\mathrm{Au}$ agglomerates, the data from bottom limits (assuming all of the $\mathrm{Au}$ species of 0.095 wt. $\% \mathrm{Au} / \mathrm{Co}_{3} \mathrm{O}_{4}$ as single $\mathrm{Au}$ atoms) is still much higher than that of 1.3 wt. $\% \mathrm{Au} / \mathrm{Co}_{3} \mathrm{O}_{4}$, which clearly indicates that the $\mathrm{Au}_{1} / \mathrm{Co}_{3} \mathrm{O}_{4} \mathrm{SACs}$ behave higher capability for $\mathrm{O}_{2}$ activation compared with $\mathrm{Au} / \mathrm{Co}_{3} \mathrm{O}_{4}$ catalysts. 


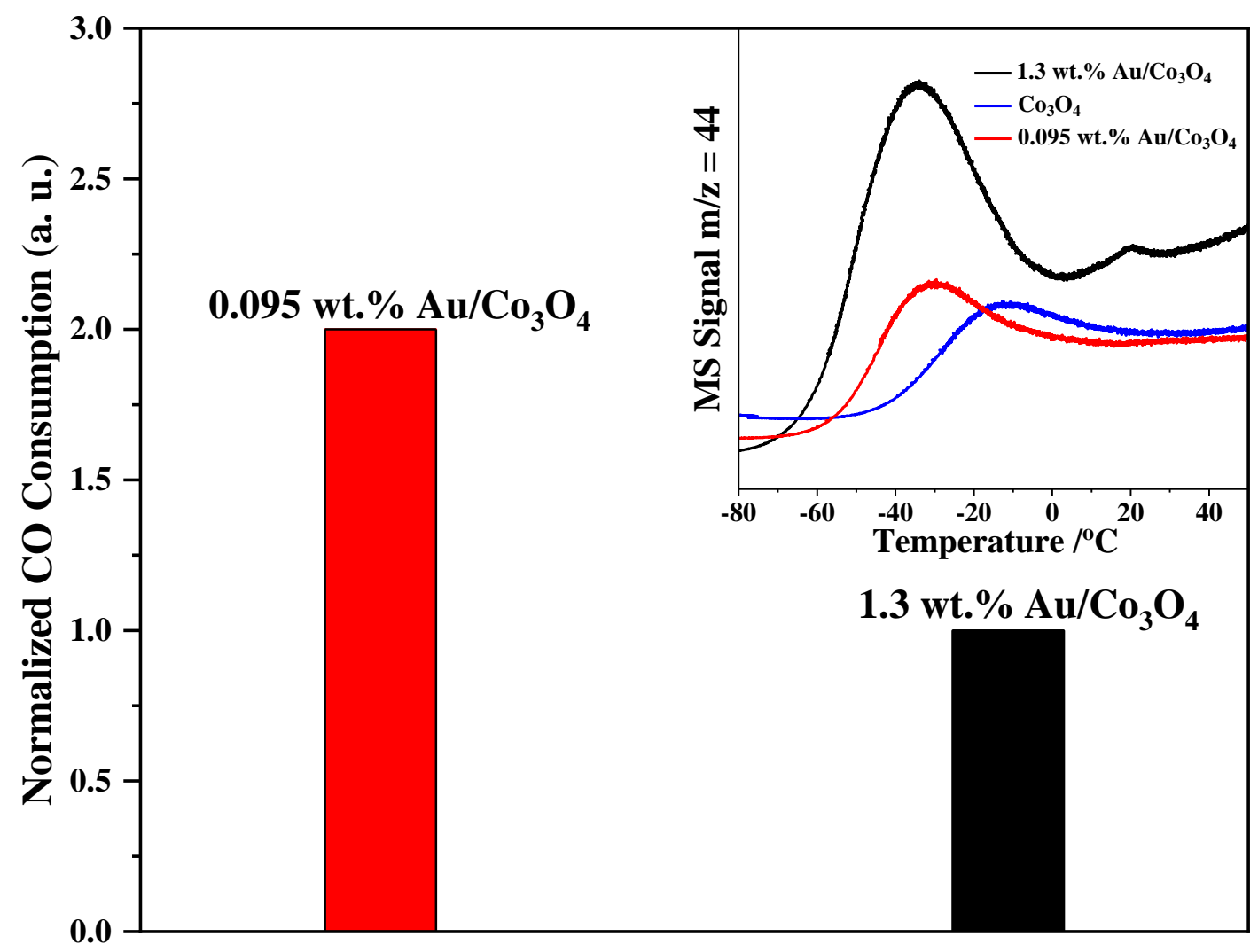

Figure S14 The low-temperature programmed CO surface reaction (CO-TPSR) over $\mathrm{Co}_{3} \mathrm{O}_{4}, 1.3$ wt.\% $\mathrm{Au} / \mathrm{Co}_{3} \mathrm{O}_{4}$ and 0.095 wt.\% $\mathrm{Au} / \mathrm{Co3}_{4}$.

The adsorbed oxygen on catalyst surface is regarded as playing an important role in surface reaction. ${ }^{4-8}$ Therefore, the surface reaction of $\mathrm{CO}$ and adsorbed oxygen species is taken as a very important clue to identify the catalytic activity. Obvious $\mathrm{CO}$ consumption of $1.3 \mathrm{wt} . \% \mathrm{Au} / \mathrm{Co}_{3} \mathrm{O}_{4}$ and $0.095 \mathrm{wt} . \% \mathrm{Au} / \mathrm{Co}_{3} \mathrm{O}_{4}$ starts from $-80{ }^{\circ} \mathrm{C}$ and $-70{ }^{\circ} \mathrm{C}$ respectively, which can be ascribed to the contribution of surface weakly adsorbed molecular oxygen species. ${ }^{4}$ However, $\mathrm{CO}$ consumption over pure $\mathrm{Co}_{3} \mathrm{O}_{4}$ starts only around $-50{ }^{\circ} \mathrm{C}$, which indicates that the activation of adsorbed oxygen is enhanced significantly on 1.3 wt.\% $\mathrm{Au} / \mathrm{Co}_{3} \mathrm{O}_{4}$ and 0.095 wt.\% $\mathrm{Au} / \mathrm{Co}_{3} \mathrm{O}_{4}$.

Meanwhile, the low-temperature CO-TPSR curves clearly show that the amount of consumed $\mathrm{CO}$ from 0.095 wt. $\% \mathrm{Au} / \mathrm{Co}_{3} \mathrm{O}_{4}$ and 1.3 wt. $\% \mathrm{Au} / \mathrm{Co}_{3} \mathrm{O}_{4}$ significantly increases by about 1.3 and 3.1 times respectively compared with that of pure $\mathrm{Co}_{3} \mathrm{O}_{4}$, which indicates that the presence of $\mathrm{Au}$ species greatly enhances the $\mathrm{O}_{2}$ activation. After subtracting CO-TPSR peak area of pure $\mathrm{Co}_{3} \mathrm{O}_{4}$, the peak area normalized to the total $\mathrm{Au}$ atoms of $1.3 \mathrm{wt} . \% \mathrm{Au} / \mathrm{Co}_{3} \mathrm{O}_{4}$ and $0.095 \mathrm{wt} . \% \mathrm{Au} / \mathrm{Co}_{3} \mathrm{O}_{4}$ can characterize the capability of $\mathrm{O}_{2}$ activation of these two $\mathrm{Au} / \mathrm{Co}_{3} \mathrm{O}_{4}$ catalysts. The capability of $\mathrm{O}_{2}$ activation per $\mathrm{Au}$ atom of $0.095 \mathrm{wt} . \% \mathrm{Au} / \mathrm{Co}_{3} \mathrm{O}_{4}$ is around 2.0 times higher than that of 1.3 wt. $\% \mathrm{Au} / \mathrm{Co}_{3} \mathrm{O}_{4}$. Although the 0.095 wt. $\% \mathrm{Au} / \mathrm{Co}_{3} \mathrm{O}_{4}$ contains single Au atoms and $\mathrm{Au}$ agglomerates, the data from bottom limits (assuming all of the $\mathrm{Au}$ species of 0.095 wt. $\% \mathrm{Au} / \mathrm{Co}_{3} \mathrm{O}_{4}$ as single $\mathrm{Au}$ atoms) is still much higher than that of $1.3 \mathrm{wt} . \% \mathrm{Au} / \mathrm{Co}_{3} \mathrm{O}_{4}$, which clearly indicates that the $\mathrm{Au}_{1} / \mathrm{Co}_{3} \mathrm{O}_{4} \mathrm{SACs}$ behave higher capability for $\mathrm{O}_{2}$ activation compared with $\mathrm{Au} / \mathrm{Co}_{3} \mathrm{O}_{4}$ catalysts. 


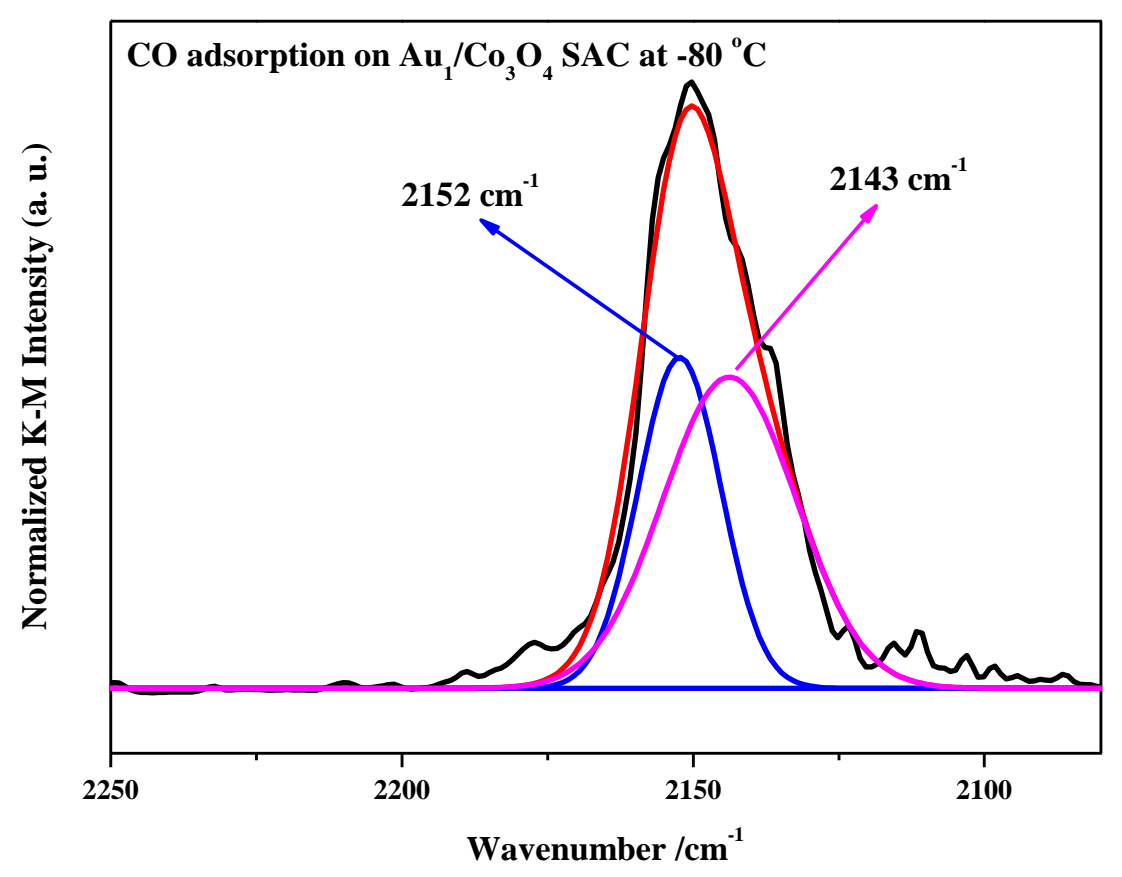

Figure S15 Fitting results of CO-DRIFTS of fresh 0.067 wt. $\% \mathrm{Au}_{1} / \mathrm{Co}_{3} \mathrm{O}_{4} \mathrm{SAC}$ at $-80{ }^{\circ} \mathrm{C}$.

The CO-DRIFTS peak of 0.067 wt. $\% \mathrm{Au}_{1} / \mathrm{Co}_{3} \mathrm{O}_{4} \mathrm{SAC}$ is deconvoluted as $\mathrm{Au}^{3+}$ (centered at $\left.2152 \mathrm{~cm}^{-1}\right)$ and $\mathrm{Au}^{\delta+}\left(1<\delta<3\right.$, centered $\left.2143 \mathrm{~cm}^{-1}\right)$ according to the published data $\left(2,152 \mathrm{~cm}^{-1}\right.$ for $\mathrm{Au}^{3+}-\mathrm{CO}$ species ${ }^{9}$ and $2138 \mathrm{~cm}^{-1}$ for $\mathrm{Au}^{+}-\mathrm{CO}$ species $\left.{ }^{10}\right)$, which is in line with the Bader charge analysis (Figure S12). Moreover, the peak area of $\mathrm{Au}^{\delta+}$ species $(1<\delta<3)$ is around 1.5 times to that of $\mathrm{Au}^{+}$species, which is in line with the ratio (1.7) of $\mathrm{C}^{16} \mathrm{O}^{18} \mathrm{O}$ (produced via $\mathrm{Au}_{1} / \mathrm{O}_{\mathrm{v}}-\mathrm{Co}_{3} \mathrm{O}_{4}$ active site) and $\mathrm{C}^{16} \mathrm{O}_{2}$ (produced via $\mathrm{Au}_{1} / \mathrm{Co}_{3} \mathrm{O}_{4}$ active site) in isotope-labeling experiments of ${ }^{18} \mathrm{O}_{2}+\mathrm{CO}$ as shown in Figure $6 \mathrm{~b}$ in the main manuscript. Therefore, it is arguable but reasonable to assign the deconvoluted $\mathrm{Au}^{3+}$ and $\mathrm{Au}^{\delta+}(1<\delta<3)$ species as the active site in $\mathrm{Au}_{1} / \mathrm{O}_{v^{-}}$ $\mathrm{Co}_{3} \mathrm{O}_{4}$ and $\mathrm{Au}_{1} / \mathrm{Co}_{3} \mathrm{O}_{4}$, respectively. These results further confirm the co-presence of two active sites and the $\mathrm{Au}_{1} / \mathrm{O}_{\mathrm{v}}-\mathrm{Co}_{3} \mathrm{O}_{4}$ sites are the predominant active site in $\mathrm{Au}_{1} / \mathrm{Co}_{3} \mathrm{O}_{4} \mathrm{SAC}$. 


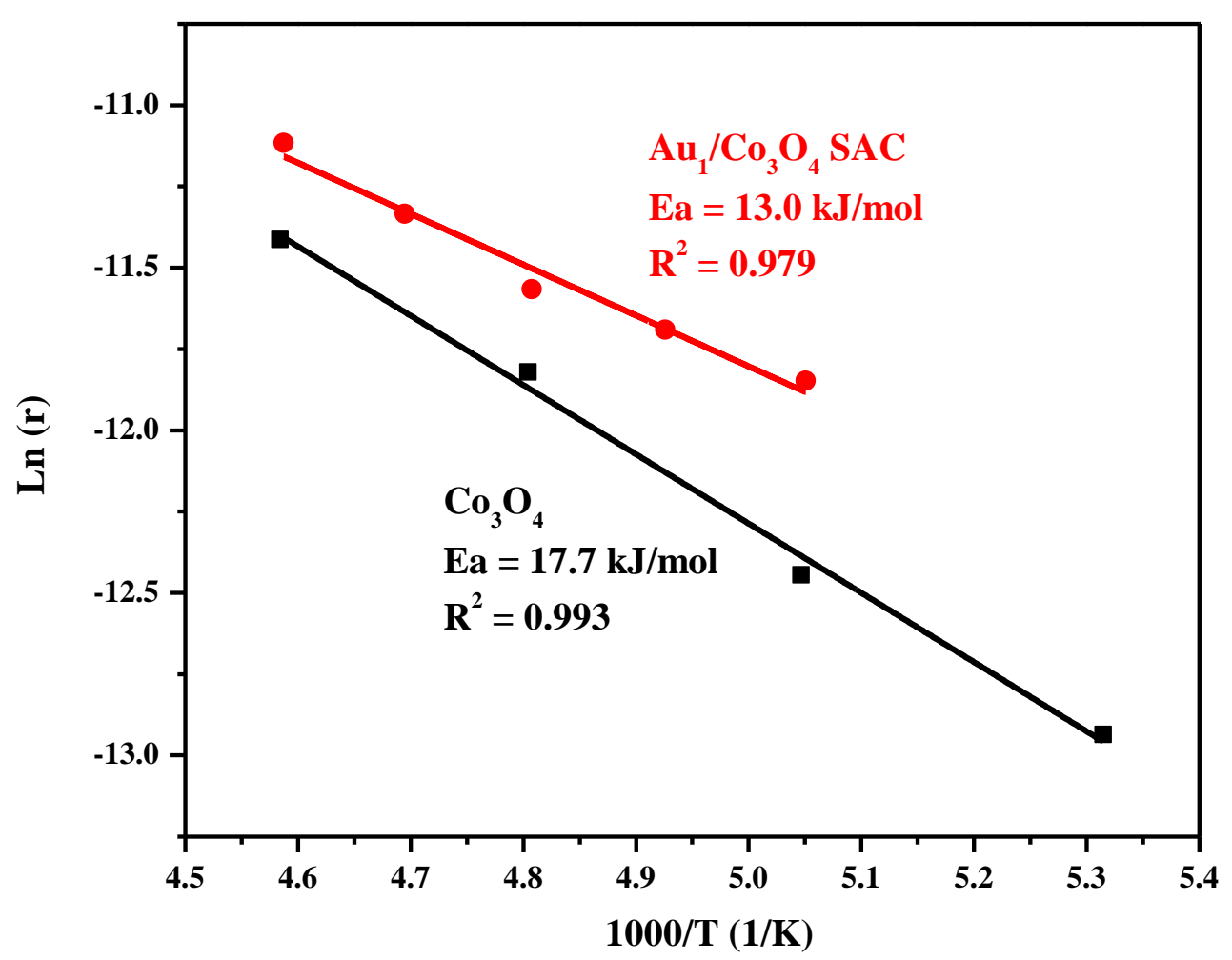

Figure S16 Reaction kinetics of $\mathrm{CO}$ oxidation over $\mathrm{Co}_{3} \mathrm{O}_{4}$ and $\mathrm{Au}_{1} / \mathrm{Co}_{3} \mathrm{O}_{4} \mathrm{SAC}$ samples. Arrhenius plots for the reaction rate constants (apparent activation energies, $E_{\mathrm{a}}$ ) on $\mathrm{Co}_{3} \mathrm{O}_{4}$ (square symbols), and $0.067 \mathrm{wt} . \% \mathrm{Au}_{1} / \mathrm{Co}_{3} \mathrm{O}_{4} \mathrm{SAC}$ (circle symbols) in the temperature (T) range of -85 to $-55{ }^{\circ} \mathrm{C}$ with a feed gas of 2.0 vol.\% $\mathrm{CO}+10$ vol. $\% \mathrm{O}_{2} / \mathrm{N}_{2}$.

As shown in Figure S16, the apparent activation energy is $17.7 \mathrm{~kJ} / \mathrm{mol}$ over $\mathrm{Co}_{3} \mathrm{O}_{4}$, which is in line with the previous data on $\mathrm{CO}$ oxidation over $\mathrm{Co}_{3} \mathrm{O}_{4}$ nanorods and $\mathrm{Co}_{3} \mathrm{O}_{4}$ particles. ${ }^{4,11}$ When the majority of Au species is in the form of single $\mathrm{Au}$ atoms on the surface of $\mathrm{Co}_{3} \mathrm{O}_{4}$, the $E_{\mathrm{a}}$ of $\mathrm{CO}$ oxidation over 0.067 wt. $\% \mathrm{Au}_{1} / \mathrm{Co}_{3} \mathrm{O}_{4} \mathrm{SAC}$ is 13.0 $\mathrm{kJ} / \mathrm{mol}(0.13 \mathrm{eV}$, calculated based on the conversion of $1 \mathrm{eV}=96.485 \mathrm{~kJ} / \mathrm{mol})$, which is in line with the DFT calculation results on the $G^{\ddagger}$ of the PathwayL-H $(0.14 \mathrm{eV})$. This also explains the high activity of $\mathrm{Au}_{1} / \mathrm{Co}_{3} \mathrm{O}_{4} \mathrm{SAC}$ from the aspect of kinetics. 


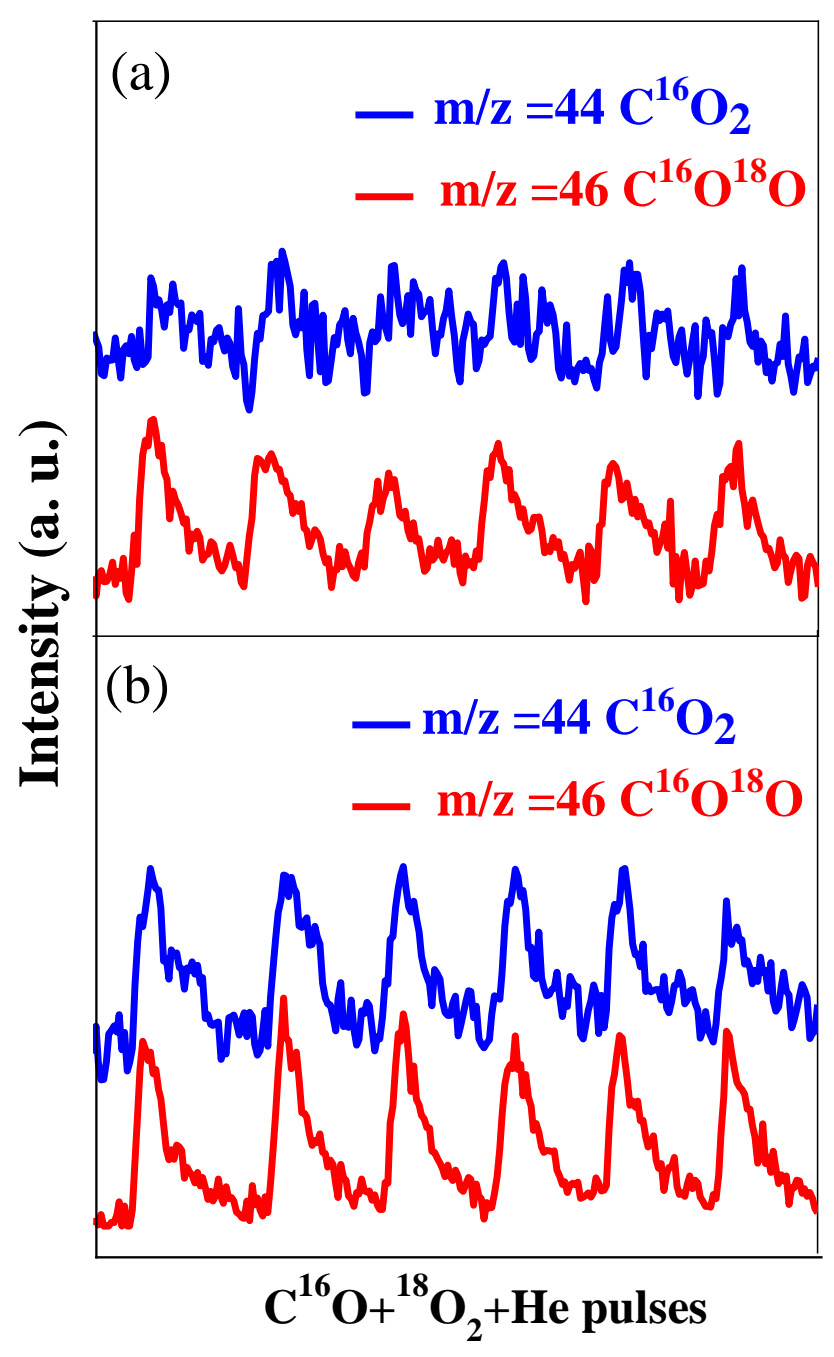

Figure S17 Time-dependent mass spectra of $\mathrm{C}^{16} \mathrm{O}_{2}$ and $\mathrm{C}^{16} \mathrm{O}^{18} \mathrm{O}$ species during $\mathrm{C}^{16} \mathrm{O}+{ }^{18} \mathrm{O}_{2}$ pulse reaction over 0.047 wt. $\%$ Au $1 / \mathrm{Co3}_{4}$ SAC. a: $-40{ }^{\circ} \mathrm{C}$; b: $-20{ }^{\circ} \mathrm{C}$. The intensity of $\mathrm{Y}$-axis stands for the intensity of mass spectra signals. The interval time is 1 minute for pulse reaction.

As shown in Figure S17, with the increase of reaction temperature for $\mathrm{C}^{16} \mathrm{O}+{ }^{18} \mathrm{O}_{2}$ pulse reaction, we can clearly observe that 1 ) the ratio of $\mathrm{C}^{16} \mathrm{O}_{2}$ to $\mathrm{C}^{16} \mathrm{O}^{18} \mathrm{O}$ is gradually increased from $-40{ }^{\circ} \mathrm{C}$ to $-20{ }^{\circ} \mathrm{C}$, which indicates that more and more lattice oxygen species are activated and participate the catalytic reactions; 2 ) the reaction channel for activating molecular oxygen species is much more active than that for activating lattice oxygen species, which suggests that the channel involving molecular oxygen activation is the predominate reaction channel. The experimental results of temperature-dependent pulse reaction is completely in line with the DFT calculation results that the reaction barrier for pathway with activated molecular oxygen species reacting with adsorbed $\mathrm{CO}$ $\left(\mathrm{G}^{\ddagger}=0.14 \mathrm{eV}\right.$, following Langmuir-Hinshelwood mechanism) is much lower by 3 times than that of lattice oxygen species reacting with adsorbed $\mathrm{CO}\left(\mathrm{G}^{*}=0.32 \mathrm{eV}\right.$, following Mars-van Krevelen mechanism). 
Table S1 Thermodynamic quantities for $\mathrm{CO}, \mathrm{O}_{2}$ and $\mathrm{CO}_{2}$ gases at experiment condition $\left(-75^{\circ} \mathrm{C}, 1 \mathrm{~atm}\right)$

\begin{tabular}{ccccccc}
\hline Gas & $\mathcal{S C}_{P} d T$ & $T S_{t}$ & $T S_{r}$ & $T S_{v}$ & $Z P E$ & $D$ \\
\hline $\mathrm{CO}$ & 0.03 & 0.29 & 0.09 & 0.00 & 0.13 & 0.00 \\
$\mathrm{O}_{2}$ & 0.04 & 0.30 & 0.09 & 0.00 & 0.10 & 0.00 \\
$\mathrm{CO}_{2}$ & 0.03 & 0.31 & 0.12 & 0.00 & 0.31 & 0.02 \\
\hline
\end{tabular}

$C_{P}$ refers to heat capacity; $S_{v}$ refers to vibrational contribution to entropy; ZPE refers to intrinsic zero-point energy; D refers to extrinsic dispersion corrections.

Table S2 Thermodynamic quantities for different states along reaction mechanism at experiment condition $\left(-75^{\circ} \mathrm{C}, 1 \mathrm{~atm}\right)$

\begin{tabular}{lllll}
\hline States & $\mathcal{S} C_{P} d T$ & $T S_{v}$ & $Z P E$ & $D$ \\
\hline $\mathrm{Au}_{1} / \mathrm{O}_{\mathrm{v}}-\mathrm{Co}_{3} \mathrm{O}_{4}$ & 0.00 & 0.00 & 0.00 & 0.00 \\
$\mathrm{CO} *+\mathrm{O}_{2} *$ & 0.12 & 0.25 & 0.32 & -0.25 \\
$\mathrm{TS} 1$ & 0.09 & 0.19 & 0.34 & -0.27 \\
$\mathrm{O}^{*}$ & 0.05 & 0.10 & 0.09 & -0.05 \\
$\mathrm{Au}_{1} / \mathrm{Co}_{3} \mathrm{O}_{4}$ & 0.01 & 0.01 & 0.09 & -0.17 \\
$\mathrm{CO}^{*}$ & 0.07 & 0.14 & 0.33 & -0.29 \\
$\mathrm{TS}$ & 0.07 & 0.13 & 0.30 & -0.26 \\
$\mathrm{CO}_{2} *$ & 0.08 & 0.15 & 0.33 & -0.31 \\
\hline
\end{tabular}

$C_{P}$ refers to heat capacity; $S_{v}$ refers to vibrational contribution to entropy; ZPE refers to intrinsic zero-point energy; D refers to extrinsic dispersion corrections. 
Table S3 Local optimized geometry structures of $\mathrm{Au}_{1} / \mathrm{Co}_{3} \mathrm{O}_{4} \mathrm{SAC}$ and the binding energy of single $\mathrm{Au}$ atom on $\mathrm{Co}_{3} \mathrm{O}_{4}(001)$

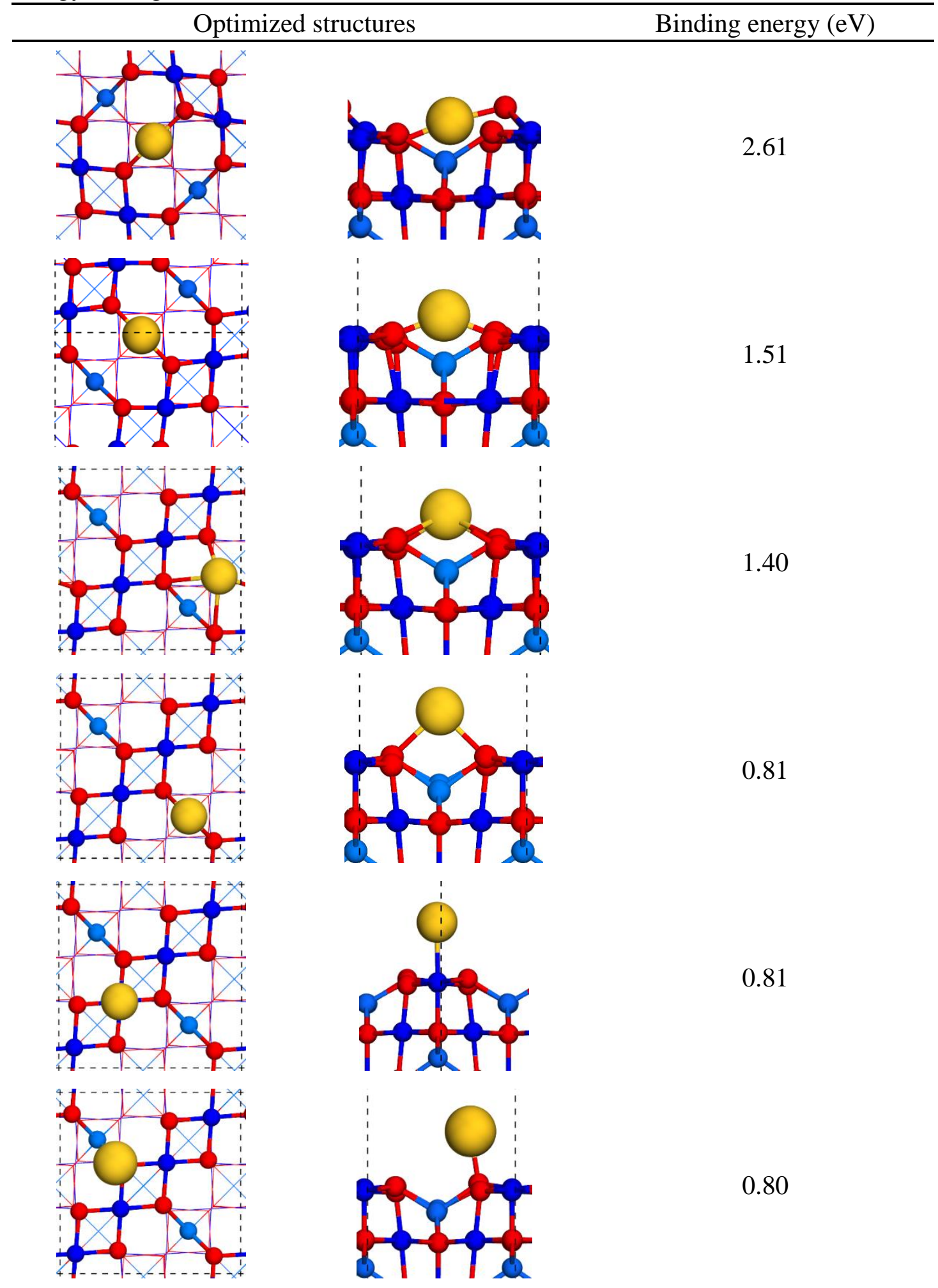

As shown in Table S3, from the binding energy of all the optimized structures, the system is most stable when $\mathrm{Au}$ is in $\mathrm{O}-\mathrm{Au}-\mathrm{O}$ linear configuration. In this structure one lattice oxygen is separated from the subsurface $\mathrm{Co}$, which makes the lattice oxygen more active. Simultaneously, this Co ion in subsurface conversion to unsaturated, which makes its magnetic moments change to $2.54 \mu \mathrm{B}$ from $0.00 \mu \mathrm{B}$. 
Table S4 The charge of Au atom in different states along reaction mechanism

\begin{tabular}{ll}
\hline States & Charge \\
\hline $\mathrm{Au}_{1} / \mathrm{O}_{\mathrm{v}}-\mathrm{Co}_{3} \mathrm{O}_{4}$ & 0.003 \\
$\mathrm{CO} *+\mathrm{O}_{2} *$ & 0.059 \\
$\mathrm{TS} 1$ & 0.135 \\
$\mathrm{O} *$ & 0.085 \\
$\mathrm{Au}_{1} / \mathrm{Co}_{3} \mathrm{O}_{4}$ & 0.457 \\
$\mathrm{CO}^{*}$ & 0.458 \\
$\mathrm{TS}_{2}$ & 0.443 \\
$\mathrm{CO}_{2} *$ & 0.453 \\
\hline
\end{tabular}

As shown in Table S4, Au has a sufficient positive charge and behaves like an ion as long as $\mathrm{Au}$ is in a linear configuration. Similarly, Au takes with a small number of charges and demonstrates the properties of metals or natural $\mathrm{Au}$ atom as long as $\mathrm{Au}$ adsorbed in lattice oxygen vacancy.

Table S5 The calculated TOF of CO oxidation, surface main species and most key step over $\mathrm{Co}_{3} \mathrm{O}_{4}$ and $\mathrm{Au}_{1} / \mathrm{Co}_{3} \mathrm{O}_{4} \mathrm{SAC}$ based on microkinetic simulation upon DFT calculations

\begin{tabular}{lcc}
\hline & $\mathrm{Co}_{3} \mathrm{O}_{4}$ & $\mathrm{Au}_{1} / \mathrm{Co}_{3} \mathrm{O}_{4} \mathrm{SAC}$ \\
\hline TOF & $5.08 \times 10^{-13} \mathrm{~s}^{-1}$ & $7.20 \times 10^{4} \mathrm{~s}^{-1}$ \\
Surface main species & $\mathrm{O}_{2}^{*}+\mathrm{CO}^{*}$ & $\mathrm{CO} *$ \\
Key step & $\mathrm{O}_{2}^{*} \rightarrow \mathrm{O}^{*}+\mathrm{O}_{\text {lat }}$ & $\mathrm{CO}^{*}+\mathrm{O}_{\text {lat }} \rightarrow \mathrm{CO}_{2}^{*}$ \\
\hline
\end{tabular}




\section{Supplemental Experimental Procedures}

\section{Activity test and kinetic data mesurement}

The activity of catalysts for $\mathrm{CO}$ oxidation was tested in a continuous flow fixed-bed quartz reactor at atmospheric pressure. In each test, $200 \mathrm{mg}$ catalyst (40 60 mesh) was used. The feed gas containing 1.0 vol.\% CO, 20.0 vol. $\% \mathrm{O}_{2}$ and $\mathrm{N}_{2}$ balance, passed through the catalytic bed at a flow rate of $50 \mathrm{~mL} \mathrm{~min}{ }^{-1}$ at atmospheric pressure (space velocity $=15,000 \mathrm{~mL} \cdot \mathrm{g}^{-1} \cdot \mathrm{h}^{-1}$ ). The concentrations of $\mathrm{CO}$ and $\mathrm{CO}_{2}$ in the outlet stream were measured by an on-line gas chromatograph (Fuli 9790 equipped with hydrogen flame ionization detector). Before testing, the catalyst was pre- treated at $300{ }^{\circ} \mathrm{C}$ for $40 \mathrm{~min}$ in 20.0 vol. $\% \mathrm{O}_{2} / \mathrm{N}_{2}\left(50 \mathrm{~mL} \mathrm{~min}{ }^{-1}\right)$. The dry feed gas was obtained by passing the feed gas through cooled trap. The operation temperature was controlled with a thermocouple and could be adjusted in the range of -100 to $400{ }^{\circ} \mathrm{C}$. Temperatures measured during the catalytic tests were always referred to the value measured in the catalyst bed. The temperature was ramped with a rate of $10{ }^{\circ} \mathrm{C}$ every 3 minutes from $100{ }^{\circ} \mathrm{C}$ to the final temperature. $\mathrm{CO}$ conversion $\left(\mathrm{X}_{\mathrm{CO}}\right)$ is calculated according to the following equation (1).

The specific reaction rates were measured under the reaction condition of 2.0 vol. \% CO, 10.0 vol.\% $\mathrm{O}_{2}$ balanced with $\mathrm{N}_{2}$ with space velocity of 40,000 to $600,000 \mathrm{~mL} \cdot \mathrm{g}^{-1} \cdot \mathrm{h}^{-1}$ to make sure the $\mathrm{CO}$ conversion below $15 \%$ so as to eliminate the thermal effect and diffusion effect when measuring the reaction rates, but the conversion was controlled in the range of $4.6 \%$ to $12.5 \%$ in case the over-low conversion would bring the errors on measuring the reaction rates. After steady reaction for about $1 \mathrm{~h}$, the $\mathrm{CO}$ conversion rates at $57 \mathrm{~min}, 60 \mathrm{~min}$ and $63 \mathrm{~min}$ were averaged and used for calculations of the specific rates. The reaction rates were calculated based on per gram of catalyst or gold, according to the following equations:

$$
\begin{gathered}
\mathrm{X}_{\mathrm{CO}}(\%)=\frac{[\mathrm{CO}]_{\text {in }}-[\mathrm{CO}]_{\text {out }}}{[\mathrm{CO}]_{\text {in }}} \times 100 \quad(S 1) \\
\text { Rate }\left(\mathrm{g}_{\mathrm{cat}}\right)=\frac{\mathrm{X}_{\mathrm{CO}} \times[\mathrm{CO}]_{\text {in }} \times \mathrm{V}}{\mathrm{m}_{\mathrm{cat}}} \text { in }\left[\mu \mathrm{mol} \mathrm{g}_{\mathrm{cat}}^{-1} \mathrm{~s}^{-1}\right] \\
\text { Rate }\left(\mathrm{g}_{\mathrm{Au}}\right)=\frac{\mathrm{X}_{\mathrm{CO}} \times[\mathrm{CO}]_{\mathrm{in}} \times \mathrm{V}}{\omega \times \mathrm{m}_{\mathrm{cat}}}-\text { Rate }_{(\mathrm{gC} 3 \mathrm{O} 4)} \text { in }\left[\mu \mathrm{mol} \mathrm{g}_{\mathrm{Au}}^{-1} \mathrm{~s}^{-1}\right]
\end{gathered}
$$

wherein $\mathrm{V}$ is the total molar flow rate, $\mathrm{m}_{\text {cat }}$ is the mass of catalyst used in the experiment, $\omega$ is the mass ratio of gold in the $\mathrm{Au} / \mathrm{Co}_{3} \mathrm{O}_{4}$ catalyst. The turnover frequencies (TOFs) were calculated based on the specific reaction rate and the gold content using the following equation:

$$
\mathrm{TOF}=\frac{\text { Rate }\left(\mathrm{g}_{\mathrm{Au}}\right)}{n_{A u}} \text { in }\left[\mathrm{s}^{-1}\right]
$$

where $\mathrm{n}_{\mathrm{Au}}$ is the molar content of the $\mathrm{Au} / \mathrm{Co}_{3} \mathrm{O}_{4}$ catalysts used in the measurements. It should be noted that the contribution of pure $\mathrm{Co}_{3} \mathrm{O}_{4}$ support was subtracted when calculating the TOF values.

\section{Gibbs free energy calculation}

Gibbs free energy calculation has been carried out as it follows:

$$
G=E+\int C_{P} d T-T S
$$


where $G, E$ and $C_{P}$ refer to the chemical potential (partial molar Gibbs free energy), electronic energy and heat capacity, respectively. The entropy term can be expressed as the sum of the translational, rotational, vibrational and electronic contributions as to:

$S=S_{t}+S_{r}+S_{v}+S_{e}$

And finally, intrinsic zero-point energy (ZPE) and extrinsic dispersion (D) corrections can be included to finally obtain:

$G=E+\int C_{P} d T-T\left(S_{t}+S_{r}+S_{v}+S_{e}\right)+Z P E+D$

Since $S_{e} \approx 0$ at the fundamental electronic level, Table S1 gathers the thermodynamic quantities for $\mathrm{CO}, \mathrm{O}_{2}$ and $\mathrm{CO}_{2}$ gases at experiment condition $\left(-73^{\circ} \mathrm{C}, 1 \mathrm{~atm}\right)$.

For the case of solids and adsorbates, some approximations can be assumed:

1. As for gases, at the fundamental electronic level $S_{e} \approx 0$.

2. Translational and rotational motions can be neglected, therefore, $S_{t} \approx 0$ and $S_{r} \approx$ 0 . In this sense, all entropy contributions comes from vibrations: $S=S_{v}$. Similarly, translational and rotational contributions to the heat capacity are neglected.

Therefore, Gibbs free energies for the different states have been calculated as to:

$G=E+\int C_{P} d T-T S_{v}+\mathrm{ZPE}+\mathrm{D}$

\section{Kinetic details}

Using the De Donder relations ${ }^{12}$, the net rate for elementary step $i$ in term of the forward rate constant, $k_{i}$, the coverage of the reactant on two different sites, $\theta(j)$, and the reversibility, $Z_{i}$, can be written as:

$r_{i}=k_{i} \prod_{j} \theta(j)^{v_{i j}}\left(1-Z_{i}\right)$

where $Z_{i}=\Pi \theta(j)^{v_{i j}} / K_{e q, i}$, which approaches zero as step $i$ becomes irreversible and approaches unity as step $i$ becomes quasi-equilibrated. $K_{e q, i}$ is the equilibrium constant of step $i$, determined by the standard Gibbs free energy change $\left(-\Delta G_{i}\right)$ of the elementary reaction, $K_{e q, i}=e^{-\Delta G / R T} . v_{i j}$ are the stoichiometric coefficients for the $j$ reactants or products of step $i$. The rate constant, $k_{i}$, for the elementary step can be determined by the transition state theory:

$$
k_{i}=k_{B} T / h \times e^{-G_{a} / R T}=k_{B} T / h \times e^{\Delta S / R} \times e^{-E_{a} / R T}
$$

where $\mathrm{kB}$ and $\mathrm{h}$ are boltzmann constant and planck constant, respectively; notably, the term $k_{B} T / h \times e^{\Delta S / R}$ corresponds to the so-called pre-exponential (A) following the Arrhenius definition for the rate constant $\left(k_{i}=A \times e^{-E_{a} / R T}\right)$. The standard equilibrium constant $K_{\text {eq,i, }}$, and rate constant $k_{i}$ can be calculated with the DFT data including the 
entropy effects. Under the steady-state condition, we can solve the kinetic equations together with the condition that the coverages of all species on $\mathrm{Co}$ and $\mathrm{O}_{\mathrm{vac}}$ are equal to 1 , respectively. It is worth noting that, for an irreversible step, $Z_{i}$ always approaches zero, while for the quasi-equilibrated step, $Z_{i}$ always approaches unity.

To distinguish the relative importance of each elementary step in determining the overall catalytic activity, the "degree of rate control" was used here ${ }^{13,14}$, which provides a quantitative measure of the sensitivity for each step in the whole reaction scheme. According to Campbell's definition, the "degree of rate control" $\left(\mathrm{X}_{\mathrm{RC}, \mathrm{i}}\right)$ for the step $i$ can be expressed in term of the standard state Gibbs free energy of the transition state as:

$$
X_{R C, i}=\frac{k_{i}}{r}\left(\frac{\partial r}{\partial k_{i}}\right)_{j \neq i, K_{c q, i}}=\left(\frac{\partial \ln r}{\partial \ln k_{i}}\right)_{j \neq i, K_{c q, i}}=\left(\frac{\partial \ln r}{\partial\left(-G_{i}^{0, T S} / R T\right)}\right)_{G_{G \neq i}^{0, T S}, G_{m}^{0}}
$$

where the partial derivative is taken by holding the standard state Gibbs free energy of all other transition state for step $j \neq i$ and all intermediate m constant, which is the same as holding the rate constants $\left(k_{j}\right)$ and the equilibrium constant $\left(K_{e q, j}\right)$ constant $(j$ $\neq i$ ). Here, keeping $K_{e q, i}$ constant means that $k_{i+}$ and $k_{i-}$ must be changed together, whose ratio remains constant. Changing the Gibbs free energy of the transition state of step $i$ while nothing else is changed can determine the influence of step $i$ on the overall reaction rate in the whole mechanism. The value of $X_{R C, i}$ for step $i$ is larger, the influence of this step $i$ on the overall reaction rate is bigger.

Also, here we used the collision theory to handle the kinetics of molecular adsorption process and to derive the equivalent barriers. According to the transition state theory and collision theory, the reaction rate on a per site basis can be written as:

$$
r_{+}(T)=\frac{k_{B} T}{h} \times e^{\left(-\frac{E_{a}}{k_{B} T}\right)} \times \frac{P_{i}}{P^{0}} \approx S_{i}(T) \frac{P_{i} A_{0}}{\sqrt{2 \pi k_{B} m_{i} T}}
$$

where $k_{\mathrm{B}}, h, T, P_{\mathrm{i}}$ and $m_{i}$ are Boltzmann constant, Planck constant, reaction temperature, pressure and the mass of gas molecule, respectively. $A_{0}$ is the area of the atom which is described as $A_{0}=\pi r^{2}$, in which $r$ is the VDW radius of the atom. Herein, we have assumed that the gas behaves ideally, $S_{i}(T)$, the sticking coefficient, is seen as 1 . Hence we could get an equation about the equivalent barriers $\left(E_{a}\right)$ :

$E_{a} \approx-k_{B} T \ln \left(\frac{P^{0} A_{0} h}{k_{B} T \sqrt{2 \pi k_{B} m_{i} T}}\right)$

In the microkinetic calculation, we have taken the experimental condition, $0.01 \mathrm{~atm}$ $\mathrm{CO}, 0.21 \mathrm{~atm} \mathrm{O}_{2}$ and $T=-75{ }^{\circ} \mathrm{C}$. 


\section{Supplemental References}

(1) Wang, H. F.; Kavanagh, R.; Guo, Y. L.; Guo, Y.; Lu, G. Z.; Hu, P. Origin of extraordinarily high catalytic activity of $\mathrm{Co}_{3} \mathrm{O}_{4}$ and its morphological chemistry for $\mathrm{CO}$ oxidation at low temperature. J. Catal. 2012, 296, 110-119.

(2) Lou, Y.; Wang, L.; Zhao, Z. Y.; Zhang, Y. H.; Zhang, Z. G.; Lu, G. Z.; Guo, Y.; Guo, Y. L. Low-temperature $\mathrm{CO}$ oxidation over $\mathrm{Co}_{3} \mathrm{O}_{4}$-based catalysts: Significant promoting effect of $\mathrm{Bi}_{2} \mathrm{O}_{3}$ on $\mathrm{Co}_{3} \mathrm{O}_{4}$ catalyst. Appl. Catal. B:Environ. 2014, 146, 43-49. (3) Lou, Y.; Wang, L.; Zhang, Y. H.; Zhao, Z. Y.; Zhang, Z. G.; Lu, G. Z.; Guo, Y. The effects of $\mathrm{Bi}_{2} \mathrm{O}_{3}$ on the $\mathrm{CO}$ oxidation over $\mathrm{Co}_{3} \mathrm{O}_{4}$. Catal. Today 2011, 175, 610-614.

(4) Yu, Y. B.; Takei, T.; Ohashi, H.; He, H.; Zhang, X. L.; Haruta, M. Pretreatments of $\mathrm{Co}_{3} \mathrm{O}_{4}$ at moderate temperature for $\mathrm{CO}$ oxidation at $-80{ }^{\circ} \mathrm{C} . J$. Catal. 2009, 267, 121128.

(5) Liotta, L. F.; Di Carlo, G.; Pantaleo, G.; Deganello, G. $\mathrm{Co}_{3} \mathrm{O}_{4} / \mathrm{CeO}_{2}$ and $\mathrm{Co}_{3} \mathrm{O}_{4} / \mathrm{CeO}_{2}-\mathrm{ZrO}_{2}$ composite catalysts for methane combustion: Correlation between morphology reduction properties and catalytic activity. Catal. Commun. 2005, 6, 329336.

(6) Blik, H. F. J. van 't; Prins, R. Characterization of supported cobalt and cobaltrhodium catalysts I. Temperature-programmed reduction (TPR) and oxidation (TPO) of $\mathrm{Rh} / \mathrm{Al}_{2} \mathrm{O}_{3}$. J. Catal. 1986, 97, 188-199.

(7) Vandenbossche, M.; McIntosh, S. The rate and selectivity of methane oxidation over $\mathrm{La}_{0.75} \mathrm{Sr}_{0.25} \mathrm{Cr}_{\mathrm{x}} \mathrm{Mn}_{1-\mathrm{x}} \mathrm{O}_{3-\delta}$ as a function of lattice oxygen stoichiometry under solid oxide fuel cell anode conditions. J. Catal. 2008, 255, 313-323.

(8) Hu, L. H., Sun, K. Q., Peng, Q., Xu, B. Q., Li, Y. D. Surface active sites on $\mathrm{Co}_{3} \mathrm{O}_{4}$ nanobelt and nanocube model catalysts for $\mathrm{CO}$ oxidation. Nano Res. 2010, 3, 363-368.

(9) Karpenko, A.; Leppelt, R.; Plzak, V.; Behm, R. The role of cationic $\mathrm{Au}^{3+}$ and nonionic $\mathrm{Au}^{0}$ species in the low-temperature water-gas shift reaction on $\mathrm{Au} / \mathrm{CeO}_{2}$ catalysts. J. Catal. 2007, 252, 231-242.

(10) Guo, L. W.; Du, P. P.; Fu, X. P.; Ma, C.; Zeng, J.; Si, R.; Huang, Y. Y.; Jia, C. J.; Zhang, Y. W.; Yan, C. H. Contributions of distinct gold species to catalytic reactivity for carbon monoxide oxidation. Nat. Commun. 2016, 7, 13481.

(11) Xie, X.; Li, Y.; Liu, Z. Q.; Haruta, M.; Shen, W. Low-temperature oxidation of $\mathrm{CO}$ catalysed by $\mathrm{Co}_{3} \mathrm{O}_{4}$ nanorods. Nature 2009, 458, 746-749.

(12) Dumesic, J. A. Analyses of Reaction Schemes Using De Donder Relations. $J$. Catal. 1999, 185, 496-505.

(13) Campbell, C. T. Finding the Rate-Determining Step in a Mechanism. J. Catal. 2001, 204, 520-524.

(14) Stegelmann, C.; Andreasen, A.; Campbell, C. T. Degree of rate control: how much the energies of intermediates and transition states control rates. J. Am. Chem. Soc. 2009, $131,8077-8082$. 